\title{
Barrens of gold: gonad conditioning of an overabundant sea urchin
}

\author{
Cassandra G. Pert ${ }^{1,2, *}$, Stephen E. Swearer ${ }^{2}$, Symon Dworjanyn ${ }^{3}$, Nina Kriegisch ${ }^{4}$, \\ Giovanni M. Turchini ${ }^{5}$, David S. Francis ${ }^{5}$, Tim Dempster ${ }^{1}$ \\ ${ }^{1}$ Sustainable Aquaculture Laboratory - Temperate and Tropical (SALTT), School of Biosciences, \\ University of Melbourne, Victoria 3010, Australia \\ ${ }^{2}$ National Centre for Coasts and Climate (NCCC), School of Biosciences, University of Melbourne, Victoria 3010, Australia \\ ${ }^{3}$ National Marine Science Centre, Southern Cross University, Coffs Harbour, New South Wales 2450, Australia \\ ${ }^{4}$ Institute for Marine \& Antarctic Studies, University of Tasmania, Private Bag 129, Hobart, Tasmania 7001, Australia \\ ${ }^{5}$ School of Life and Environmental Sciences, Deakin University, Geelong, Victoria 3220, Australia
}

\begin{abstract}
Overgrazing by the overabundant native purple urchin Heliocidaris erythrogramma has caused kelp-dominated reefs to shift to urchin barrens throughout southeastern Australia. These areas are characterised by low kelp abundance, low biodiversity and high urchin densities. As purple urchin gonads are a delicacy in many countries, commercial harvest from barrens could aid kelp recovery. However, the lack of macroalgae in these habitats, driven by high urchin densities, results in urchins with small, poor-quality roe that is commercially undesirable. To overcome this, we assessed whether urchin gonad quantity and quality could be improved with access to high-quality feed and optimal environmental conditions, a process known as 'gonad conditioning'. Specifically, we (1) surveyed the quality of urchins from barrens and kelp sites in Port Phillip Bay, Australia, over 18 mo and (2) tested if gonad conditioning was effective on urchins from barrens during and after the harvest season. Field surveys revealed considerable variation in gonad size across sites, habitats and collection periods (mean gonad index range: 3 to $12 \%$ ). Gonad conditioning with the best diet increased urchin gonad size by up to 2.8 times during the harvest season. Moreover, gonads of conditioned urchins from one barren were 3 times brighter in colour and contained lower concentrations of arsenic than wild urchins. In contrast, gonad conditioning at $22^{\circ} \mathrm{C}$ after the harvest season was ineffective. Our results show that targeted in-season harvest from barrens and subsequent gonad conditioning produces roe of commercial quality, promoting the use of urchin fisheries as a tool for managing urchin barrens.
\end{abstract}

KEY WORDS: Roe enhancement - Heliocidaris erythrogramma - Aquaculture - Urchin barren · Temperature $\cdot$ Purple urchin

\section{INTRODUCTION}

Grazing by overabundant sea urchins is responsible for a devastating regime shift from productive kelp beds to desolate urchin barrens in many temperate reefs worldwide (Shears \& Babcock 2002, Steneck et al. 2002, Filbee-Dexter \& Scheibling 2014b, Ling et al. 2015). The shift to urchin barrens is drastic, as these

${ }^{*}$ Corresponding author: pertcg@gmail.com habitats are characterised by an absence of macroalgae, decreased habitat complexity and high densities of sea urchins. Consequently, urchin barrens are responsible for decreases in the abundance of kelp and associated species, connectivity and gene flow among populations of reef organisms and primary productivity compared to neighbouring kelp beds (Chapman 1981, Ling 2008, Johnson et al. 2015).

(C) The authors 2018. Open Access under Creative Commons by Attribution Licence. Use, distribution and reproduction are unrestricted. Authors and original publication must be credited. 
Reducing urchin densities in barrens can reverse this community shift and lead to the re-establishment of kelp-dominated environments (reviewed by Ling et al. 2015). However, urchin density must be reduced to a level considerably lower than the initial density that caused the habitat change to return to a kelp-dominated state as the system demonstrates hysteresis (Andrew \& Underwood 1993, Ling et al. 2009, Filbee-Dexter \& Scheibling 2014b, Kriegisch et al. 2016). Ling et al. (2015) estimated that sea urchins cannot maintain barrens when their densities are below $70 \mathrm{~g} \mathrm{~m}^{-2}$, which means that virtually all urchins must be removed to restore a kelp bed. Although management attempts to reduce urchin densities have been made in the USA and Australia (Reynolds \& Newman 2015, Sanderson et al. 2016), successful, broad-scale intervention has been rare due to financial and logistical constraints of largescale culls (Tracey et al. 2014, 2015). For example, Tracey et al. (2014) estimated that it would cost A $\$ 1.6$ million to cull urchins from a $1140000 \mathrm{~m}^{2}$ bay in Tasmania with urchin densities between 0.88 and 2.38 urchin $\mathrm{m}^{-2}$ to a depth of $20 \mathrm{~m}$. Given this, creating an economic driver for sea urchin removal from barrens is likely to be a more effective approach.

Sea urchin roe is a highly prized commodity in many parts of the world, most notably Japan, where $80 \%$ of the world's total production is consumed (Sonu 1995, Andrew et al. 2002). However, world production of sea urchins has declined since 1995, thought to be due to overfishing in Chile, Japan and the USA, providing an opportunity for developing fisheries to expand and capitalize on the high demand for urchin roe (Andrew et al. 2002). Currently, Australia has small urchin fisheries in Tasmania, New South Wales and Victoria, which contribute little to worldwide production $(<1 \%$; Worthington $\&$ Blount 2003). These fisheries do not harvest sea urchins from barrens, which significantly reduces their potential catch (Worthington \& Blount 2003).

Urchin barrens are widespread in Australia, with extensive areas of barrens across most southern states. Approximately $60 \%$ of all rocky reefs in Port Phillip Bay (PPB), Victoria exist as urchin barrens and contain an estimated 4300 tons of purple urchins, Heliocidaris erythrogramma (Worthington \& Blount 2003, Johnson et al. 2015). Purple urchins are a commercially valuable species endemic to Australia. In 1995, large demand for Tasmanian purple urchin roe resulted in buyers paying $\mathrm{A} \$ 250 \mathrm{~kg}^{-1}$ of A-grade roe (Sanderson et al. 1996). Purple urchins that achieve this grade are in the early stages of the reproductive cycle have firm gonads, which are bright yellow or orange in colour and which make up at least $10 \%$ of the total urchin weight.

Commercial fisheries rarely harvest sea urchins from barrens because the low food availability in these areas results in urchins with small, poor quality roe that is unsuitable for sale (Sanderson et al. 1996, Blount \& Worthington 2002, Worthington \& Blount 2003, James et al. 2007). However, providing sea urchins with ample food and housing them in optimal conditions can improve the size and quality of urchin roe from barrens (Strongylocentrotus droebachiensis: de Jong-Westman et al. 1995, Russell 1998, Vadas et al. 2000; Evechinus chloroticus: James et al. 2007). This process, known as gonad conditioning, could allow us to view the vast numbers of urchins in barrens as a resource, rather than an ecological problem. This could create an economic driver for purple sea urchin harvest from barrens across southern Australian reefs and lead to the re-establishment of kelp-dominated ecosystems.

However, several limitations will need to be overcome before a sea urchin aquaculture industry can be successfully established. First, it is unknown whether purple urchins from barrens can generate roe of a commercial quality via the delivery of artificial feeds. Second, the harvest period for purple urchins is short ( $<5 \mathrm{mo})$, as gonad size and quality can be greatly influenced by the annual reproductive cycle (Dix 1977, Constable 1989). Spawning can occur as early as November and as late as March (Williams \& Anderson 1975, Dix 1977, Constable 1989), during which gonads lose mass and are inedible. Gonads then typically remain small and in a state of recovery before increasing in size again in winter (Dix 1977, Constable 1989). Thus, the months when purple urchins are more likely to have high quality roe are from June to October, hereafter referred to as the harvest season. Prolonging the harvest season, especially to coincide with national holidays in the Asian market (March, May, December) when demand is highest, would increase the profitability of an urchin aquaculture industry (Vadas et al. 2000). Temperature has been used to effectively control the reproductive cycle of other urchin species (Shpigel et al. 2004, Siikavuopio et al. 2006, James \& Heath 2008a). Notably, E. chloroticus conditioned at spring-summer water temperatures out of the harvest period produced larger gonads than urchins held at cooler water temperatures (James et al. 2007, James \& Heath 2008a), suggesting that manipulating temperature may allow control of the reproductive cycle of purple urchins.

Here, we assessed whether sea urchin aquaculture can effectively increase the commercial quality of 
purple urchins from barrens to encourage urchin harvest from areas where they are overabundant. Specifically, we (1) surveyed the quality of urchins from barrens and kelp sites in PPB, Australia, over $18 \mathrm{mo}$ and (2) tested if gonad conditioning was effective on urchins from barrens during and after the harvest season.

\section{MATERIALS AND METHODS}

\section{Expt 1: Spatio-temporal variability in gonad index}

To evaluate the effect of site and habitat on purple urchin gonad index (GI), we surveyed purple urchins from 2 sites, each containing kelp bed and urchin barren habitats, over 18 mo.

\section{Animal collection}

Divers collected urchins from 2 sites in PPB: Gellibrand ( $\left.37^{\circ} 52.196^{\prime} \mathrm{S}, 144^{\circ} 53.584^{\prime} \mathrm{E}\right)$ and Mornington $\left(38^{\circ} 12.833^{\prime} \mathrm{S}, 145^{\circ} 1.942^{\prime} \mathrm{E}\right)$. Gellibrand is in northern PPB and receives high urban nutrient inputs, while Mornington, in southeastern PPB, is more pristine due to lower urban development in the region (Johnson et al. 2015). The 2 sites were chosen as they contained kelp bed and urchin barren habitats. A total of 15 monthly/bimonthly collections were made from October 2012 to March 2014. During each collection, divers collected 30 urchins from both habitats at each site. Urchins with a test diameter greater than $40 \mathrm{~mm}$ were collected, as purple urchins become sexually mature at this size (Dix 1977).

\section{Data collection and analysis}

The total wet weight of each sea urchin was measured before dissecting and weighing their gonads. Total wet weight and gonad wet weight were used to calculate the GI (GI = gonad wet weight / total wet weight $\times 100$ ).

We performed a linear mixed effects analysis of the relationship between GI, site, habitat and collection period using the 'Ime4' package in $\mathrm{R}$ version 3.2.3 (R Development Core Team 2015). Site, habitat and their interaction were treated as fixed factors, while collection period was a random factor. GI was $4^{\text {th }}$-root transformed and homogeneity of variance and normality were confirmed with a plot of residuals versus predicted values. $p$-values were calculated by likeli- hood ratio tests of the full model compared with the reduced models (not containing the effect in question), followed by Tukey's post hoc tests.

\section{Expt 2: In-season gonad conditioning}

To determine whether purple urchins from barrens could be conditioned to produce roe of commercial quantity and quality, we fed urchins from barrens artificial diets for $12 \mathrm{wk}$ before assessing gonad size, colour and grade.

\section{Animal collection}

Purple urchins with a diameter between 40 and $70 \mathrm{~mm}$ were collected from 3 urchin barren sites in PPB (38.1732 $\left.{ }^{\circ} \mathrm{S}, 144.8731^{\circ} \mathrm{E}\right)$. Barren 1, in the north of PPB, contains urchin biomasses $>500 \mathrm{~g} \mathrm{~m}^{-2}$ (Johnson et al. 2015) and can receive large quantities of unattached 'drift' algae $\left(>200 \mathrm{~g} \mathrm{~m}^{-2}\right.$; Chidgey \& Edmunds 1997). Barren 2 is on the southwest coast of the Western Treatment Plant (WTP) with a sea urchin biomass of $>500 \mathrm{~g} \mathrm{~m}^{-2}$ (Johnson et al. 2015). It receives drift algae at lower volumes than Barren 1 (Chidgey \& Edmunds 1997). Barren 3, located in the Geelong Arm of PPB, has the highest sea urchin density (approximately 650 to $1100 \mathrm{~g} \mathrm{~m}^{-2}$ ) of the 3 barrens (Johnson et al. 2015) and drift biomass is likely to be negligible as most drift occurs in northern PPB (Chidgey \& Edmunds 1997). Urchins were also collected from 3 kelp bed sites in the east (Kelp bed 1), southwest (Kelp bed 2) and north (Kelp bed 3) of PPB for comparison with the urchin barrens.

Urchins were collected from the barrens in June 2016 for the 12 wk gonad-conditioning trial. We collected an additional 25 to 30 urchins from the 6 sites to assess wild urchin quality at the start and end of the experiment. The urchins were transported to the laboratory in coolers containing ambient, oxygenated seawater.

\section{Experimental design}

Urchins from the 3 barrens were randomly allocated to 201 plastic tubs $(30 \mathrm{~cm}$ long $\times 48 \mathrm{~cm}$ deep $\times$ $23 \mathrm{~cm}$ high), with 3 replicate tubs per diet $\times$ site combination and 10 urchins tub ${ }^{-1}$ (density: 20 urchins $\mathrm{m}^{-2}$ ). The tanks were supplied with flow-through ambient seawater $\left(1.01 \mathrm{~min}^{-1} ; 13.9 \pm 0.5^{\circ} \mathrm{C}\right)$ and experienced a $12 \mathrm{~h}$ light: $12 \mathrm{~h}$ dark photoperiod. 
Table 1. Proximate composition of artificial diets fed to Heliocidaris erythrogramma during gonad conditioning in Expt 2 (all diets) and Expt 3 (commercially available [COM] diet). The matching (MAT) and high-protein (HP) diets were manufactured by Deakin University, while the COM diet was a commercially available artificial urchin feed manufactured by Aquafeeds Australia. NFE = nitrogen free extract

\begin{tabular}{|lcccccc|}
\hline & $\begin{array}{c}\text { Moisture } \\
\left(\mathrm{g} \mathrm{kg}^{-1}\right)\end{array}$ & $\begin{array}{c}\text { Protein } \\
\left(\mathrm{g} \mathrm{kg}^{-1}\right)\end{array}$ & $\begin{array}{c}\text { Lipid } \\
\left(\mathrm{g} \mathrm{kg}^{-1}\right)\end{array}$ & $\begin{array}{c}\text { Ash } \\
\left(\mathrm{g} \mathrm{kg}^{-1}\right)\end{array}$ & $\begin{array}{c}\text { NFE+ others } \\
\left(\mathrm{g} \mathrm{kg}^{-1}\right)\end{array}$ & $\begin{array}{c}\text { Energy } \\
\left(\mathrm{MJ} \mathrm{kg}^{-1}\right)\end{array}$ \\
\hline MAT & 40.0 & 335.3 & 54.0 & 49.5 & 521.3 & 19.0 \\
HP & 40.0 & 453.5 & 59.2 & 59.8 & 387.5 & 19.7 \\
COM & 61.1 & 334.8 & 49.2 & 104.0 & 451.0 & 17.6 \\
\hline
\end{tabular}

The urchins were fed 1 of 3 artificial gonadconditioning diets: a commercially available diet manufactured by Aquafeeds Australia (COM); a matching diet formulated to be iso-proteic $(33 \%)$ and iso-lipidic (5\%) to the commercial diet (MAT); and a high-protein diet (HP) formulated to be iso-lipidic but with a higher protein content $(45 \%)$ compared to the other diets (Table 1). The MAT and HP diets were identical in their formulation with respect to the added quantities of vitamins, minerals, binders, materials of marine origin and supplementary crystalline amino acids (commercial-in-confidence formulation, formulation details not provided). Diets varied only in the inclusion ratio of blended terrestrial protein sources and the ratio of wheat flour and pre-gelatinised corn starch, so that the nutritional objective described above could be achieved. The 2 diets contained titanium dioxide $\left(\mathrm{TiO}_{2}\right)$ as an inert marker for subsequent estimations of digestibility. The HP and MAT diets were manufactured at Deakin University's Nutrition and Seafood Laboratory, using a small-scale extruder (DGP-50, Zhengzhou Amisy Machinery) as described in Huguet et al. (2015).

We fed the urchins for $12 \mathrm{wk}$, which is within the optimal time (9 to $12 \mathrm{wk}$ ) for gonad conditioning (Musgrove 2005, James 2006, James \& Heath 2008b). Urchins were fed ad libitum (approximately $4.0 \mathrm{~g}$ every 2 to $3 \mathrm{~d}$ ) and tanks were cleaned every 2 to $3 \mathrm{~d}$. Mortality was monitored throughout the experiment and any dead urchins were removed without replacement.

Clean faecal matter was collected from the tanks throughout the experiment and kept frozen at $-18^{\circ} \mathrm{C}$. The material was then freeze-dried at the end of the experiment for feed digestibility analysis.

\section{Data collection}

We measured the gonad quantity and quality of all urchins after the gonad conditioning trial, plus a sam- ple of wild urchins from the 6 collection sites at the start and end of the experiment.

Diameter, total wet weight, gonad wet weight and GI of each urchin was measured as outlined in Expt 1.

Gonad colour was quantified by photographing one gonad from each urchin on a white board next to a SpyderCheckr colour card (Datacolor) using a Nikon D7000 digital camera. The gonads were placed inside a photo light box, which was illuminated on 2 sides by $150 \mathrm{~W}$ lights equidistant from the centre of the white board to standardise lighting conditions. First, we linearised camera responses (red $[R]$, green $[\mathrm{G}]$, blue $[\mathrm{B}]$, and luminance values) in relation to 6 grey standards from the colour card and their measured reflectance values (Garcia et al. 2013). Second, RGB values were equalised relative to the $20 \%$ grey standard in each image to account for slight variation in illumination (Stevens et al. 2007). Further details of the linearisation and equalisation method are given in Stevens et al. (2007), Garcia et al. (2013) and Smith et al. (2016). We then calculated the standardised difference between the R and G channels as (R - G) / $(\mathrm{R}+\mathrm{G}+$ $B)$, which was defined as $x$, and the $G$ and $B$ channels as $(\mathrm{G}-\mathrm{B}) /(\mathrm{R}+\mathrm{G}+\mathrm{B})$, which was defined as $y$. This 2-dimensional representation of colour space allowed calculation of hue, chroma and brightness. We calculated hue as $\tan ^{-1}(y / x)$, chroma as $\left(x^{2}+\right.$ $\left.y^{2}\right)^{1 / 2}$ and brightness as $\mathrm{R}+\mathrm{G}+\mathrm{B}$ (Endler 1990).

In addition, each gonad was graded based on its colour, texture and firmness (Table 2, Fig. 1). Gonads were separated into 3 colour categories: (1) black, brown or grey; (2) pale yellow and orange or dark yellow and orange; and (3) bright yellow and orange. Gonads were then separated into 3 texture categories: (1) fine (<1 mm granulation); (2) medium (between 1 and $2 \mathrm{~mm}$ granulation); and (3) coarse ( $>2 \mathrm{~mm}$ granulation). Finally, gonads were deemed either firm or not firm based on their ability to hold together during dissection and when placed under 2 different weights: 72 and $175 \mathrm{~g}$. Gonads that remained whole during dissection and under at least one weight, or gonads that broke during dissection but withstood both weights were deemed 'firm'. If the gonad broke during dissection and under at least one weight, or held together during dissection but broke under both weights, it was deemed 'not firm'. Based on these attributes, the gonads were subsequently graded A, B, C or D (Table 2, Fig. 1): A-grade is premium roe, $\mathrm{B}$-grade is high-quality roe, $\mathrm{C}$-grade 
Table 2. Expt 2: grading system used to assess the commercial quality of Heliocidaris erythrogramma roe based on colour, texture and firmness. A-grade: premium quality; Bgrade: high quality; C-grade: mediocre quality; D-grade: unacceptable commercial quality. F: firm gonad; NF: not firm. See Fig. 1 for images of roe quality

\begin{tabular}{|lccc|}
\hline Colour & Texture & Firmness & Grade \\
\hline $\begin{array}{l}\text { Bright orange } \\
\text { or yellow }\end{array}$ & Fine & F & A \\
& & NF & B \\
& & F & A \\
& Coarse & NF & B \\
Pale/dark orange & Fine & NF & B \\
or yellow & & F & B \\
& Medium & NF & C \\
& & NF & B \\
& Coarse & F & C \\
Black, brown, & & NF & C \\
grey & Fine & F & D \\
& & NF & D \\
& Medium & F & D \\
& & NF & D \\
& Coarse & F & D \\
& & NF & D \\
\hline
\end{tabular}

is mediocre quality roe and D-grade is unacceptable as a commercial product.

To investigate whether the urchins from barrens were safe for consumption, we analysed the gonads for metals and non-metals of food safety interest: arsenic, cadmium, copper, lead, mercury, selenium and zinc. Although there are no specific metal limits for urchin roe in Australia, we consulted the limits for other seafood products as an indication of safe metal levels for urchin roe (arsenic: 1 to $2 \mathrm{mg} \mathrm{kg}^{-1}$; cadmium: $2 \mathrm{mg} \mathrm{kg}^{-1}$; lead: 0.5 to $2 \mathrm{mg} \mathrm{kg}^{-1}$; mercury: mean level of 0.5 to $1 \mathrm{mg} \mathrm{kg}^{-1}$; Food Standards Australia New Zealand 1991).

Pieces of gonad ( 0.05 to $0.1 \mathrm{~g}$ ) were sectioned from conditioned urchins $\left(\mathrm{n}=2 \mathrm{tank}^{-1}\right)$ and wild urchins $\left(\mathrm{n}=6\right.$ barren $\left.^{-1}\right)$ at the end of the experiment. We weighed, freeze-dried and digested the samples with nitric acid $\left(\mathrm{HNO}_{3} ; 65 \%\right.$ Suprapur, Merck) before heating them at $90^{\circ} \mathrm{C}$ for $20 \mathrm{~min}$. Hydrogen peroxide $\left(\mathrm{H}_{2} \mathrm{O}_{2} ; 30 \%\right.$ Aristar, $\left.\mathrm{BDH}\right)$ was added to the samples before heating again for $15 \mathrm{~min}$ at $70^{\circ} \mathrm{C}$. Measurements were made using an Agilent 7700 series ICP-MS instrument under routine multi-element operating conditions using a helium reaction gas cell. Calculations of metal concentration were made with reference to the wet weight of each gonadal tissue sample. We analysed the samples for multiple iso-

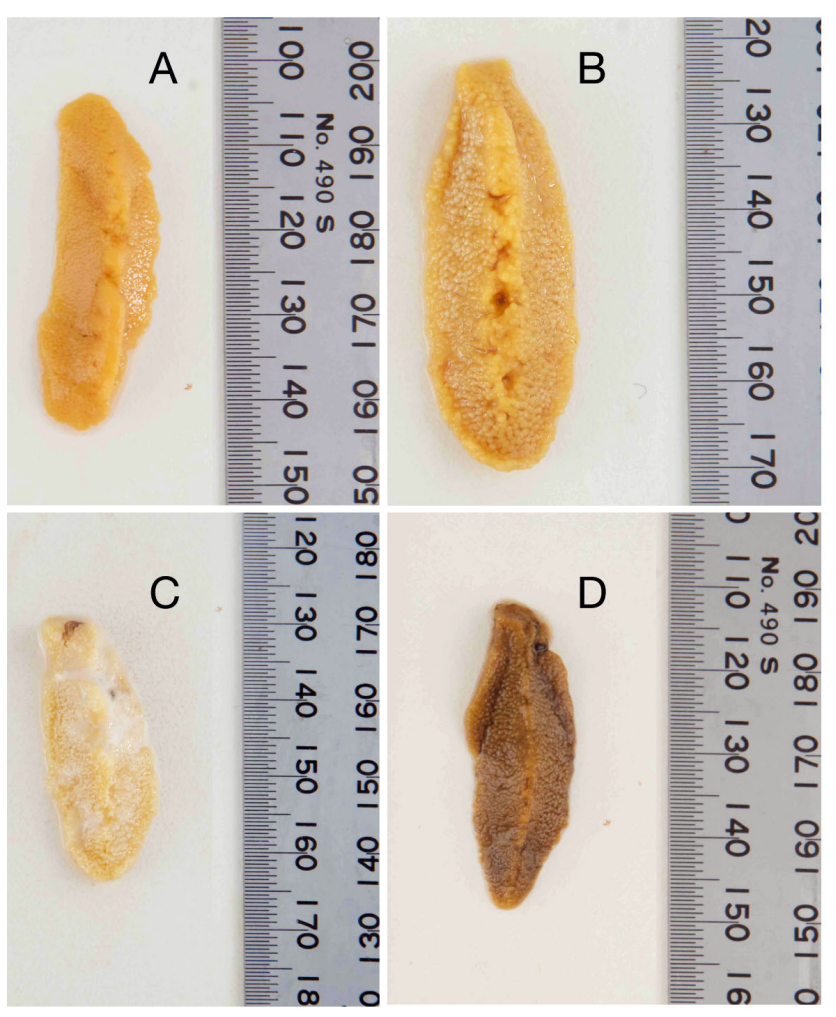

Fig. 1. Expt 2: grade system for assessing Heliocidaris erythrogramma roe quality calculated from gonad colour, texture and firmness. (A) A-grade gonads, premium quality; (B) Bgrade gonads, high commercial quality; (C) C-grade gonads, mediocre; (D) D-grade gonads, not of commercial quality. Scale in $\mathrm{mm}$

topes of lead ( $\mathrm{Pb}$ 206, $\mathrm{Pb} 207, \mathrm{~Pb} 208)$ and mercury (Hg 200, Hg 201, Hg 202) but only the isotope with all samples above the limit of detection is reported $(\mathrm{Pb}$ 207, Hg 200). All samples had concentrations of these 8 metals above detection limits $\left(\mathrm{As}^{75}: 0.11 \mathrm{ppb} \mathrm{Cd}^{111}\right.$ : 0.009 ppb; $\mathrm{Cu}^{63}: 0.012$ ppb; $\mathrm{Pb}^{207}: 0.013 \mathrm{ppb}^{2} \mathrm{Hg}^{200}$ : $\left.0.016 \mathrm{ppb}_{i} \mathrm{Se}^{78}: 0.111 \mathrm{ppb}^{2} \mathrm{Zn}^{66}: 0.084 \mathrm{ppb}\right)$.

To determine whether increased dietary protein content affected feed digestibility, we assessed the digestibility of the HP and MAT diets. $\mathrm{TiO}_{2}$ was analysed in faeces and feed samples as described by Myers et al. (2004), and apparent digestibility coefficients for dry matter were computed as previously described by Cho \& Slinger (1979).

\section{Statistical analysis}

Diameter, total wet weight, gonad weight and GI were compared among wild sites from the initial collection with 1-way ANOVA ( $\left.\mathrm{n}=25 \mathrm{site}^{-1}\right)$, followed by Tukey's post hoc tests. We used 2-way ANOVA to 
compare diameter, total wet weight, gonad weight, and GI between treatments after gonad conditioning, followed by Tukey's post hoc tests. Both site and diet were treated as fixed effects with tank as the unit of replication $(\mathrm{n}=3)$.

To compare the diameter, wet weight, gonad weight and GI of conditioned and wild urchins at the end of the experiment, we ran a 3-way ANOVA with tank nested within site and diet to determine whether there was a tank effect. As the p-value for tank was non-significant for all dependent variables (see Table S1 in the Supplement at www.int-res.com/ articles/suppl/q010p345_supp.pdf), the design was collapsed in accordance with Quinn \& Keough (2002). Analyses were subsequently performed by 2way ANOVA with urchins as replicates and 'wild' as a diet type. Due to the significant interaction between site and diet, we performed separate ANOVA for each site, followed by Tukey's post hoc tests, using the $\mathrm{MS}_{\text {Residual }}$ from the original ANOVA as the error term (Quinn \& Keough 2002).

We assessed the effect of site, diet and their interaction on gonad colour of conditioned and wild urchins with three 2-way ANOVA for chroma, hue and brightness followed by Tukey's post hoc tests. Due to the significant interaction of site and diet in each analysis, we performed separate univariate ANOVA for each site, as above. To analyse the difference in grading composition between sites and diets, we used an ordinal logistic regression model with grade scores as an ordinal response variable $(A>B>C>D)$. Separate ordinal logistic regressions were performed for each site due to the significant interaction of site and diet on grade.

The relationship between site, diet and metal concentrations was assessed with 2-way ANOVA $(n=6)$, followed by Tukey's post hoc tests. Non-normal data were $\log$ transformed or $4^{\text {th }}$-root transformed depending on their distribution. We used a Bonferroni adjusted alpha ( $\alpha=0.00625)$ to correct for multiple non-independent tests. In addition, we performed an ordinal logistic regression to analyse the effect of metal concentration on gonad grade. We conducted a principal component analysis on metal concentration and used the PC1 scores as a univariate scalar of metal concentration in the regression analysis.

The difference in apparent digestibility coefficients of the MAT and HP diets was assessed using a 1-way ANOVA. As only small amounts of faecal material were collected from each tank, we pooled the samples from the 3 replicate tanks for each diet $\times$ site combination, giving 6 samples in total. The pooled samples from the 3 sites were the unit of replication for each diet $(n=3)$. Assumptions of normality and homogeneity of variance were confirmed with plots of residuals versus predicted values for all ANOVA in Expts 2 and 3.

\section{Expt 3: Out-of-season gonad conditioning}

To determine the effect of increased water temperature on gonad conditioning of post-spawned urchins, purple urchins were conditioned under 2 temperature regimes: WARM (constant $22^{\circ} \mathrm{C}$ ) and COOLING (temperature range of 18 to $14.9^{\circ} \mathrm{C}$ to mimic seasonal decline).

\section{Experimental design}

Divers collected purple urchins (diameter: 40 to $70 \mathrm{~mm}$ ) from a rocky reef in Williamstown, northern PPB (37 $\left.52.313^{\prime} \mathrm{S}, 144^{\circ} 53.688^{\prime} \mathrm{E}\right)$ on 7 March 2016. The site has moderate urchin densities (approximately $420 \mathrm{~g} \mathrm{~m}^{-2}$ ) and is located within $5 \mathrm{~km}$ of the mouth of the Yarra River and within $30 \mathrm{~km}$ of the WTP (Johnson et al. 2015). At this time of year, sea urchins from PPB are typically in the spent/recovering phase (Constable 1989, Laegdsgaard et al. 1991). The site had an average depth of $3 \mathrm{~m}$ and a water temperature of $23^{\circ} \mathrm{C}$ at the time of collection. A sample of wild urchins $(n=25)$ was collected at the start and end of the experiment. Animals were collected and transported as described in Expt 2.

We used a temperature-controlled, UV-filtered recirculating seawater system that was adjusted to mimic seasonal seawater temperatures in PPB. The water temperature in the COOLING treatment was kept at the temperature of the seawater system. It started at $18^{\circ} \mathrm{C}\left(4^{\circ} \mathrm{C}\right.$ below site temperature at collection) and was gradually lowered by approximately 0.5 to $1^{\circ} \mathrm{C}$ every 2 to $3 \mathrm{wk}$ until reaching a minimum of $14.9^{\circ} \mathrm{C}$. WARM tanks were heated by connected warming units and remained at $22^{\circ} \mathrm{C} \pm 0.5^{\circ} \mathrm{C}$ for the trial.

The urchins were housed in 541 tanks $(60 \mathrm{~cm}$ long $\times$ $30 \mathrm{~cm}$ deep $\times 30 \mathrm{~cm}$ high), with 6 tanks treatment ${ }^{-1}$ and 10 urchins tank $\mathrm{k}^{-1}$ (density: 11 urchins $\mathrm{m}^{-2}$ ). The tanks were supplied with recycled seawater $\left(11 \mathrm{~min}^{-1}\right)$ and experienced a $12 \mathrm{~h}$ light:12 h dark photoperiod.

On arrival at the laboratory, urchins were randomly allocated to the WARM or COOLING treatments and acclimated for $7 \mathrm{~d}$. We fed the urchins a commercial gonad-conditioning diet for $10 \mathrm{wk}$ (proximate composition of 'COM' in Table 1) and monitored urchin mortality as done in Expt 2. 
Data collection and analysis

Test diameter, total wet weight, gonad wet weight, GI and gonad colour (hue, chroma and brightness) of experimental and wild urchins were measured as described in Expt 2.

The reproductive stage of a random sample of 10 urchins from each treatment and from the initial and final wild urchin collections was determined by histological analysis. Gonads were fixed in Bouin's solution for $48 \mathrm{~h}$ and dehydrated in $70 \%$ ethanol. We then embedded the samples in paraffin and cut $8 \mu \mathrm{m}$ sections. The sections were stained with standard Harris' haematoxylin and counterstained with eosin. We used the 6 reproductive stages described in Laegdsgaard et al. (1991) (spent, recovering, growing, premature, mature and partly-spawned) to assess the reproductive stage of each sample. Maximum gonad indices are reached prior to spawning (mature stage; Constable 1989); however, optimal texture and firmness is seen in recovering, growing and premature gonads (Laegdsgaard et al. 1991.

Diameter, wet weight, gonad weight and GI were contrasted between WARM and COOLING treatments using 1-way ANOVA with tanks as the unit of replication ( $\mathrm{n}=6$ treatment $^{-1}$ ). We compared WARM, COOLING and wild urchins at the end of the experiment with 1-way ANOVA, followed by Tukey's post hoc tests, after determining that there was no tank effect, as done in Expt 2 (Table S2 in the Supplement).

A survival analysis compared urchin survival between treatments. We ran a Cox proportionalhazards regression model from the 'survival' pack- age in $\mathrm{R}$ version 3.2.3 ( $\mathrm{R}$ Development Core Team 2015; $\mathrm{n}=6$ treatment $^{-1}$ ). A log-rank test compared survival distributions between the 2 treatments.

Three separate Kruskal-Wallis tests analysed the effect of treatment on gonad brightness, chroma and hue, followed by post hoc pairwise comparisons between groups. A parametric test was chosen, as the data did not satisfy ANOVA assumptions.

\section{RESULTS}

\section{Expt 1: Spatio-temporal variability in gonad index}

Mean GI varied considerably (min.: $2.7 \%$; max.: $12.5 \%$ ) among sites, habitats and sampling periods (Fig. 2, Table 3). The mean GI of Gellibrand urchins was, on average, $42 \%$ higher than Mornington urchins during the 18 mo survey (site: $\chi_{2}^{2}=714, \mathrm{p}<$ 0.001). Moreover, there was a strong relationship between habitat and GI $\left(\chi_{2}^{2}=160, \mathrm{p}<0.001\right)$ with the GI of urchins from kelp beds being $20 \%$ greater, on average, than urchins from barrens at the same site ( $<<0.001 ;$ Fig. 2). The interaction between site and habitat had no effect on GI $\left(\chi^{2}{ }_{1}=0.58, \mathrm{p}=0.4\right)$.

Urchins from both sites followed similar reproductive cycles over the collection period with peak mean GI in November and December (Gellibrand: $10.5 \pm$ $0.4 \%$; Mornington: $6.6 \pm 0.6 \%$ ), followed by sharp reductions in GI after summer spawning (Fig. 2). However, urchins from Gellibrand showed greater changes in GI compared to Mornington urchins, which showed less GI variation between collections.

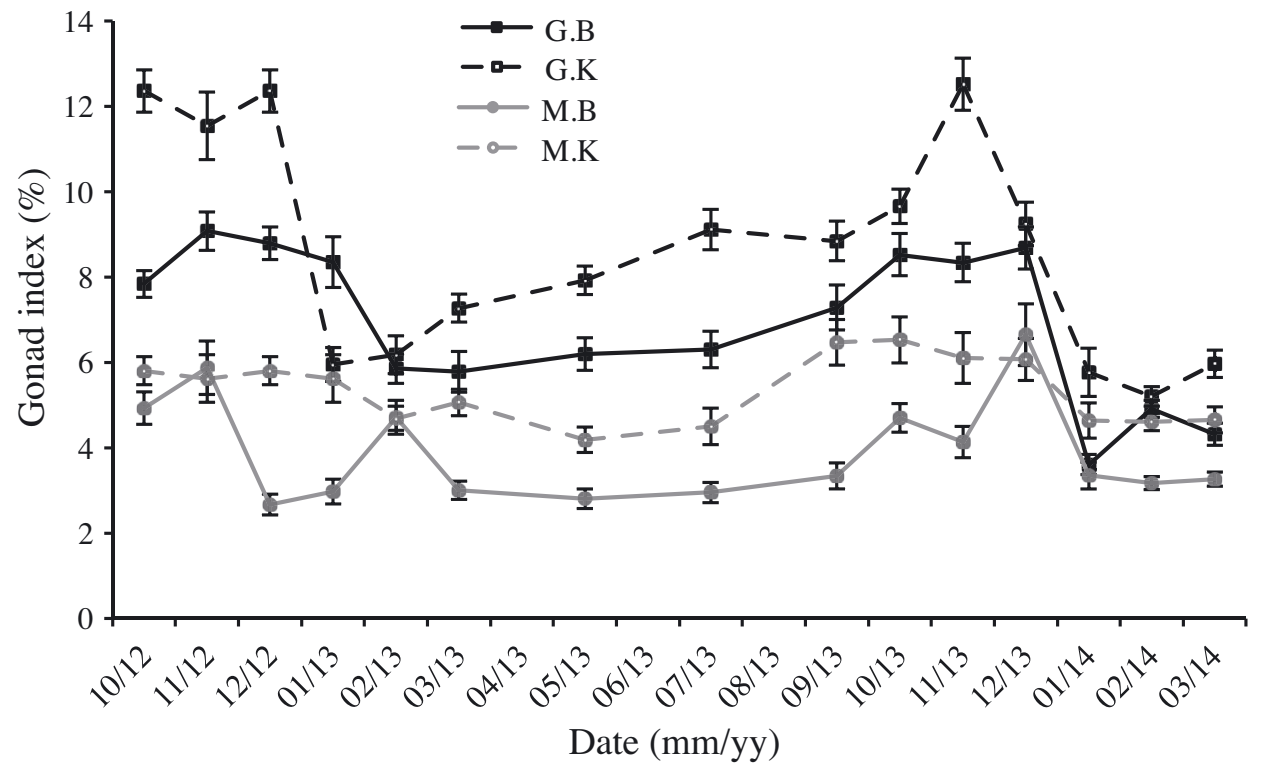

Fig. 2. Expt 1: mean \pm SE gonad index of purple urchins Heliocidaris erythrogramma from Gellibrand urchin barrens (G.B; dark grey, solid line) and kelp beds (G.K; dark grey, dashed line), and Mornington urchin barrens (M.B; light grey, solid line) and kelp beds (M.K; light grey, dashed line). Urchins were collected monthly or bimonthly from October 2012 to March 2014 
Table 3. Expt 1: linear mixed-effects model for the difference in 4th-root transformed gonad index (GI) of Heliocidaris erythrogramma between urchins at 2 sites, Gellibrand (G) and Mornington (M) collected from October 2012 to March 2014. Both sites contained urchin barren (B) and kelpbed $(\mathrm{K})$ habitats. Site, habitat and their interaction were treated as fixed factors, while collection period was random. See Fig. 2 for GI values

\begin{tabular}{|lcccc|}
\hline Fixed factor & Estimate & SE & $p$ & Post hoc test \\
\hline Intercept & 1.59 & 0.02 & $<0.001$ & \\
Site & -0.22 & 0.01 & $<0.001$ & $\mathrm{G}>\mathrm{M}$ \\
Habitat & 0.09 & 0.01 & $<0.001$ & $\mathrm{~K}>\mathrm{B}$ \\
Site $\times$ habitat & 0.01 & 0.01 & 0.45 & \\
Random factor & $\mathrm{n}$ & Variance & $\mathrm{SD}$ & \\
Period & 15 & 0.01 & 0.08 & \\
Residual & 1798 & 0.03 & 0.16 & \\
\hline
\end{tabular}
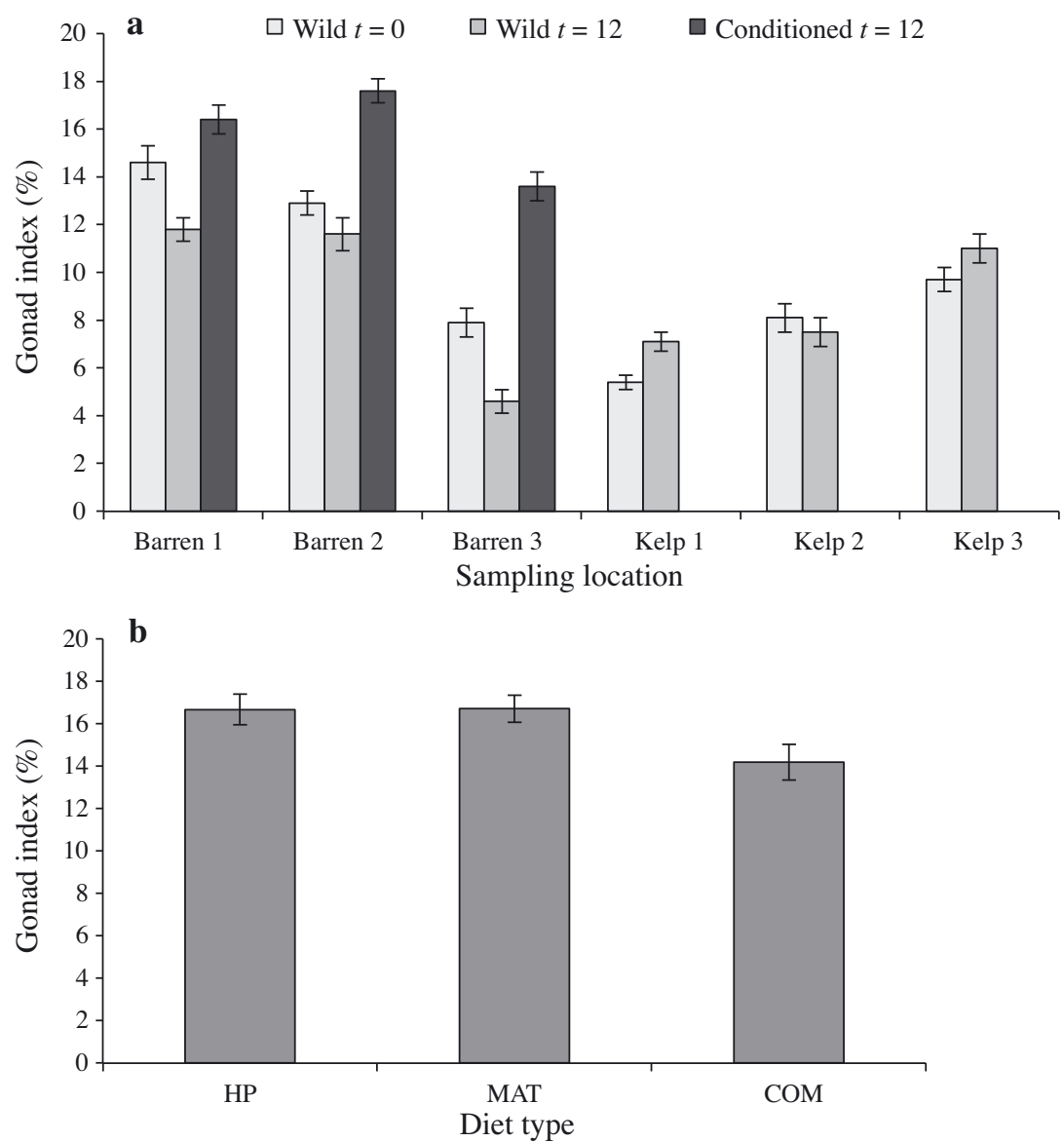

Fig. 3. Expt 2: mean $\pm \mathrm{SE}$ gonad index of purple sea urchins Heliocidaris erythrogramma (a) from 3 barren sites and 3 kelp-bed sites in Port Phillip Bay, Victoria. Light grey bars: wild urchins collected at the start of the experiment (June-July 2016); medium grey bars: urchins collected from the wild 12 wk later (September 2016); dark grey bars: urchins fed gonadconditioning diets for $12 \mathrm{wk}$ (average of the 3 diets); (b) fed 3 pellet diets for 12 wk: a high-protein diet (HP), a commercially available diet (COM) and a diet which was iso-proteic and iso-lipidic as the COM diet but had a different formulation (MAT; see Table 1)

\section{Expt 2: In-season gonad conditioning}

Gonad quantity and urchin size comparisons

Wet weight $\left(F_{5,145}=41, \mathrm{p}<0.001\right)$, diameter $\left(F_{5,145}=37, \mathrm{p}<0.001\right)$, gonad weight $\left(F_{5,145}=19, \mathrm{p}<0.001\right)$ and GI $\left(F_{5,145}=44, \mathrm{p}<0.001\right.$; Fig. 3a) differed among wild urchins from the 6 sites. Wild urchins from kelp-bed sites were, on average, $63 \%$ heavier ( $p<0.01$; kelp: $98 \pm 2$ $\mathrm{g}$, barren: $60 \pm 2 \mathrm{~g}$ ) and $16 \%$ larger in diameter ( $<<0.01$; kelp: $62 \pm 0.6 \mathrm{~mm}$, barren: $53 \pm 0.5 \mathrm{~mm}$ ) than urchins from barrens. The mean GI of urchins from barren sites was $57 \%$ greater than urchins from kelp beds (kelp: $7 \pm 0.3 \%$; barren: $12 \pm$ $0.5 \%$; Fig. 3a) with urchins from Barrens 1 and 2 recording the highest mean GI $(14.6 \pm 3.4$ and $12.9 \pm 2.3 \%$, respectively; Fig. 3a; Tukey's post hoc test: $p<0.05$ compared to other sites). Despite urchins from barrens being consistently smaller in weight and diameter than urchins from kelp beds, there was no clear effect of habitat type on gonad weight (kelp: $3.3 \pm 0.4 \mathrm{~g}$, barren: $3.6 \pm 0.4 \mathrm{~g}$ ).

Diet and site affected the GI (diet: $F_{2,18}$ $=10, \mathrm{p}<0.01$; site: $\left.F_{2,18}=19, \mathrm{p}<0.001\right)$ and gonad weight (diet: $F_{2,18}=8, \mathrm{p}<$ 0.01 ; site: $F_{2,18}=54, \mathrm{p}<0.001$ ) of experimental urchins. The mean GI of urchins fed the HP and MAT diets was 1.2 times higher than the mean GI of urchins fed the COM diet (Fig. 3b; $p<0.01$ for all pairwise comparisons). Over $28 \%$ of urchins fed the MAT diet had a GI over $20 \%$, compared to $23 \%$ of urchins fed the HP diet and $12 \%$ of urchins fed the COM diet. Similarly, the mean gonad weight of urchins fed the HP diet was $16 \%$ heavier than urchins fed the COM diet ( $p<0.01$; HP: $10.5 \pm 0.8$ g; COM: 9.0 $\pm 0.8 \mathrm{~g}$ ). In contrast, diet had no effect on urchin diameter $\left(F_{2,18}=3, \mathrm{p}<0.05\right)$ or weight $\left(F_{2,18}=2, \mathrm{p}<0.05\right)$.

Urchins from Barrens 1 and 2 had a higher GI compared to urchins from Barren 3 after gonad conditioning ( $p<0.05$; Fig. 3a). However, conditioned urchins from Barren 3 had a 1.7 times mean increase in GI compared to their starting 
GI, which was almost double the mean GI increase of Barren 2 urchins and over 5 times the GI increase of urchins from Barren 1 (Fig. 3a). The most successful site/diet combination was urchins from Barren 2 fed the HP diet, with a mean GI of $18 \pm 1.4 \%$ and a maximum GI of $30 \%$.

Only 5 urchins died during the trial, which was less than $2 \%$ of all urchins.

Diet had a varying impact on GI depending on where the urchins were collected (site $\times$ diet: $F_{6,342}=$ 2 , $\mathrm{p}<0.05)$. For all sites, diet was a significant predictor of GI (Barren 1: $F_{3,342}=10, \mathrm{p}<0.001$; Barren 2: $F_{3,342}=15, \mathrm{p}<0.001 ;$ Barren 3: $\left.F_{3,342}=35, \mathrm{p}<0.001\right)$. Urchins from Barren 3 and Barren 2 fed any of the manufactured diets had a higher mean GI (1.4 to 3.6 times higher) compared to wild urchins ( $\mathrm{p}<$ 0.001). The GI of urchins from Barren 1 fed the HP or MAT diets were, on average, 1.5 times higher than that of wild urchins ( $p<0.001)$. In addition, the mean GI of conditioned urchins from the barrens $(15.9 \pm 0.5 \%)$ was $87 \%$ higher than the GI of wild urchins from the kelp bed sites, which is where the traditional urchin fishery exists (GI: 8.5 $\pm 1.2 \%$; Fig. 3a).

\section{Gonad quality}

The baseline collection of wild urchins revealed significant differences in gonad brightness, chroma and hue among the 6 sites (brightness: $F_{5,145}=12, \mathrm{p}<0.001$; chroma: $F_{5,145}=6, \mathrm{p}<0.001$; hue: $F_{5,145}=$ $2, \mathrm{p}<0.05)$. Most notably, urchins from Barren 3 and Kelp bed 3 had darker gonads (lower brightness) than urchins from the other 4 sites ( $p<0.05$ for all comparisons).

Comparing experimental urchins, the interaction between site and diet had an effect on gonad chroma, brightness and hue (chroma: $F_{6,341}=8, \mathrm{p}<0.001$; brightness: $F_{6,341}=10, p<0.001$; hue: $F_{6,341}=4$, $\mathrm{p}<0.001)$. Diet influenced gonad colour of urchins from Barren 3 (chroma: $F_{3,341}=$ $34, \mathrm{p}<0.001$; brightness: $F_{3,341}=37, \mathrm{p}<$ 0.001; hue: $F_{3,341}=11, \mathrm{p}<0.001$ ) with wild urchins having gonads that were darker (lower brightness, Fig. 4a), purer in colour (higher chroma, Fig. 4b), and more yellow (larger hue value, Fig. 4c) than conditioned urchins $(p<0.05$ for all comparisons). Diet affected the chroma of urchin gonads from Barren $2\left(F_{3,341}=4, \mathrm{p}<0.001\right)$, with wild urchins having gonads of higher chroma than urchins fed the artificial diets ( $p<0.05$ for all comparisons; Fig. 4b). However, diet had no effect on the gonad brightness or hue of Barren 2 urchins (brightness: $F_{3,341}=1.5$, hue: $F_{3,341}=0.7, \mathrm{p}<0.05$ for both tests) or on any measure of gonad colour for Barren 1 urchins (brightness: $F_{3,341}=0.7$, chroma: $F_{3,341}=0.6$, hue: $F_{3,341}$ $=0.8, \mathrm{p}<0.05$ for all tests).

The interaction of site and diet affected gonad grade scores $\left(\chi_{6}^{2}=42, \mathrm{p}<0.01\right.$; Fig. 5). This interaction was primarily driven by Barren 3 urchins, which had considerably poorer grade scores than the other barrens (Fig. 5). Grade composition differed by diet for Barren 3 urchins $\left(\chi_{3}^{2}=27, \mathrm{p}<0.01\right)$ with $73 \%$ of wild urchins graded D compared with $26 \%$ of conditioned urchins (Fig. 5c). Grade composition also dif-
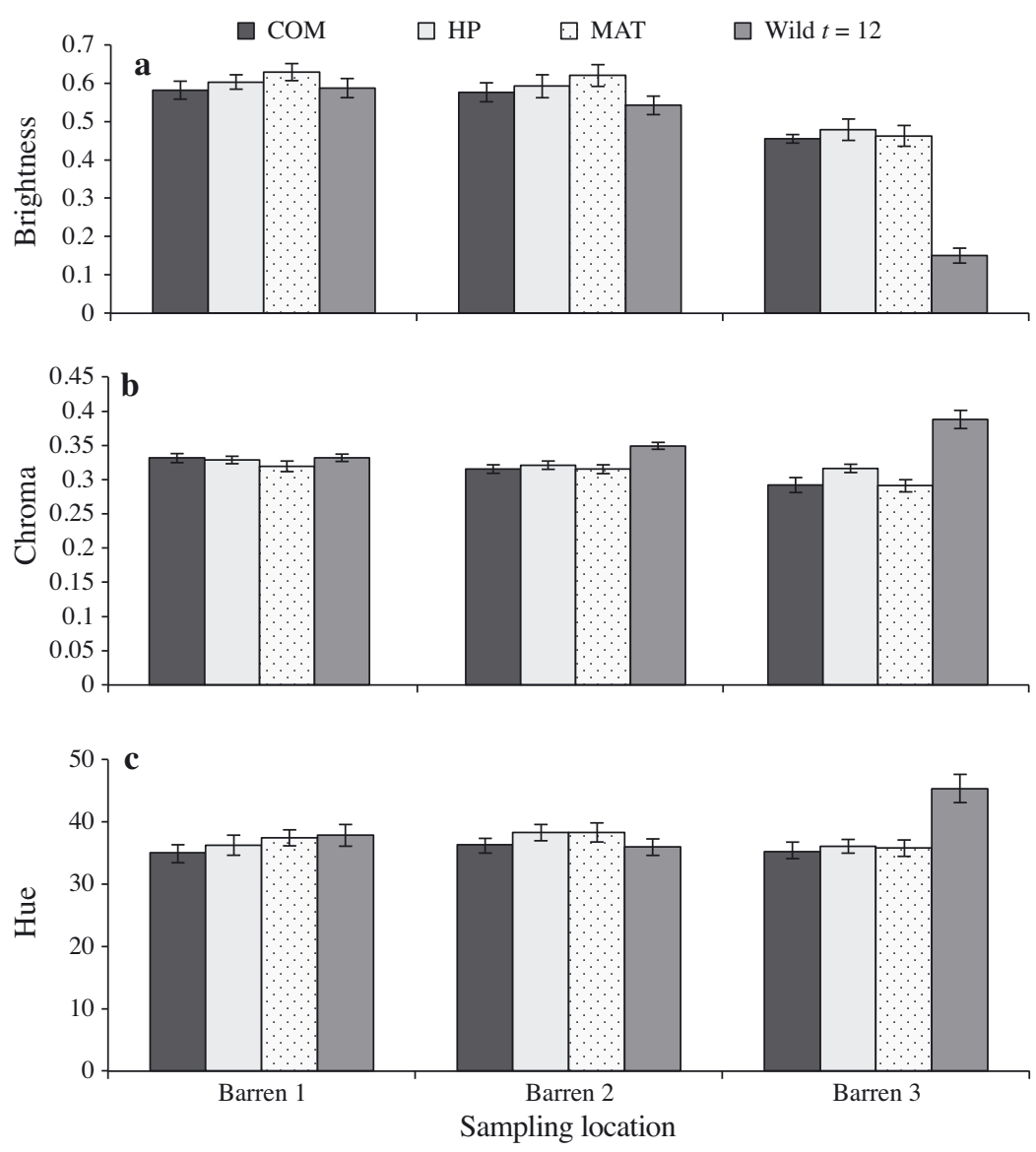

Fig. 4. Expt 2: Mean \pm SE gonad colour between purple urchins from 3 urchin barrens in Port Phillip Bay, Victoria. These urchins were fed 1 of 3 pellet diets for $12 \mathrm{wk}$ : a commercially available diet (COM; dark grey bars), a high-protein diet (HP; light grey bars) and a diet which had the same protein level as the commercial diet but was made with different ingredients (MAT; dotted bars) or were collected from the wild (Wild $t=12$; medium grey bars). The colour of each gonad was assessed in terms of its (a) brightness, (b) chroma and (c) hue 

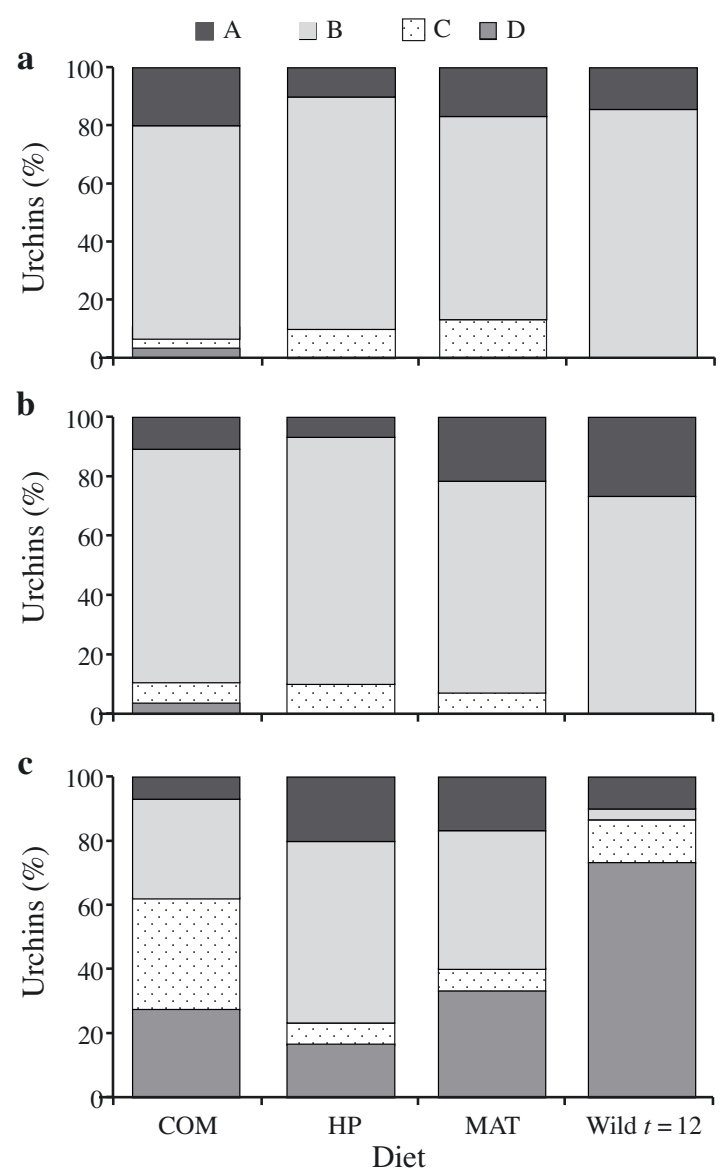

Fig. 5. Expt 2: percentage of purple urchins with A-, B-, C- or D-grade gonads from 3 urchin barrens in Port Phillip Bay, Victoria, fed 3 pellet diets for $12 \mathrm{wk}$ and urchins from the wild (Wild $t=12$ ). The pellet diets were a commercially available feed (COM), a high-protein feed (HP) and a feed that had the same protein and lipid levels as the COM diet but was made using different ingredients (MAT). Data are from (a) Barren 1, (b) Barren 2 and (c) Barren 3. The grading was ordinal, with A as the highest grade and $\mathrm{D}$ the lowest grade

fered by diet for Barren 2 urchins $\left(\chi_{3}^{2}=11, \mathrm{p}<0.05\right)$, however, urchins from the wild had more A-grade roe $(27 \%)$ than conditioned urchins $(13 \%$; Fig. $5 b)$. In contrast, grade was relatively uniform for Barren 1 , irrespective of diet. $\left(\chi_{3}^{2}=3, p<0.05\right.$; Fig. 5a)

Metal analysis and diet digestibility

The mean arsenic concentrations of urchins from Barren 3, regardless of diet, were all within or above the range of maximum arsenic levels (Table 4). All wild urchins sampled from Barren 3 had arsenic concentrations above maximum food safety limits for seafood ( $2 \mathrm{mg} \mathrm{kg}^{-1}$; Table 4$)$. Only one gonad-conditioned urchin (MAT diet) had arsenic concentrations above this threshold. All concentra- tions of cadmium, lead and mercury in this study were below food safety maximum levels.

Barren 3 urchins, regardless of diet, had the highest mean concentrations of arsenic, cadmium, selenium and mercury (Table 4). Wild urchins from Barren 3 had the highest mean concentrations of all elements, excluding chromium and zinc (Table 4). Site and diet influenced arsenic and lead concentrations (Table 5). Barren 3 urchins contained over 3 times the arsenic and lead concentrations of urchins from the other barrens $(p<0.001)$ and wild urchins had approximately double the mean arsenic concentration and over 4 times the mean lead concentration compared to conditioned urchins, regardless of site $(\mathrm{p}<0.05)$. The interaction of site and diet influenced mercury and cadmium concentrations (Table 5). Barren 3 urchins had the highest mean concentrations of cadmium and mercury when collected from the wild (Table $4 ; \mathrm{p}<0.05$ ), while there was no effect of diet on cadmium or mercury concentrations of Barren 2 and Barren 1 urchins ( $p>0.05)$. Selenium concentration varied by site, with Barren 3 urchins containing double the mean selenium concentrations of the other barrens (Table $5 ; \mathrm{p}<0.001$ ). There was no effect of site or diet on the concentrations of copper, chromium or zinc (Table 5).

Metal concentration was a significant predictor of grade $\left(\chi_{1}^{2}=38, p<0.01\right)$. Sea urchins with brown or black gonads (D-grade gonads) had higher levels of arsenic (3.5 times), mercury (6.3 times), selenium (2 times), cadmium (9.8 times) and lead (6.1 times), on average, than urchins with gonads of a higher grade.

The mean percent apparent dry matter digestibility coefficients of the HP and MAT diets were $80 \pm 3$ and $69 \pm 5 \%$, respectively. However, there was no statistical difference between the 2 digestibility coefficients $\left(F_{1,4}=3, \mathrm{p}>0.05\right)$.

\section{Expt 3: Out-of-season gonad conditioning}

Gonad quantity and urchin size comparisons

In March, wild urchins had a mean test diameter of $63.8 \pm 0.6 \mathrm{~mm}$ and a mean wet weight of $91.8 \pm 2.2 \mathrm{~g}$. The mean weight of their gonads was $7.0 \pm 0.3 \mathrm{~g}$ and their mean GI was $7.6 \% \pm 0.3$ (Fig. 6a).

After gonad conditioning, experimental urchins in the WARM treatment had a lower mean GI $\left(F_{1,10}=14\right.$, $\mathrm{p}<0.01$; Fig. $6 \mathrm{a})$ and mean gonad weight $\left(F_{1,10}=6\right.$, $\mathrm{p}<0.05)$ compared to urchins in the COOLING treatment. The mean GI of WARM urchins was $7.1 \pm$ $0.8 \%$, which was a decrease from the mean GI of the 


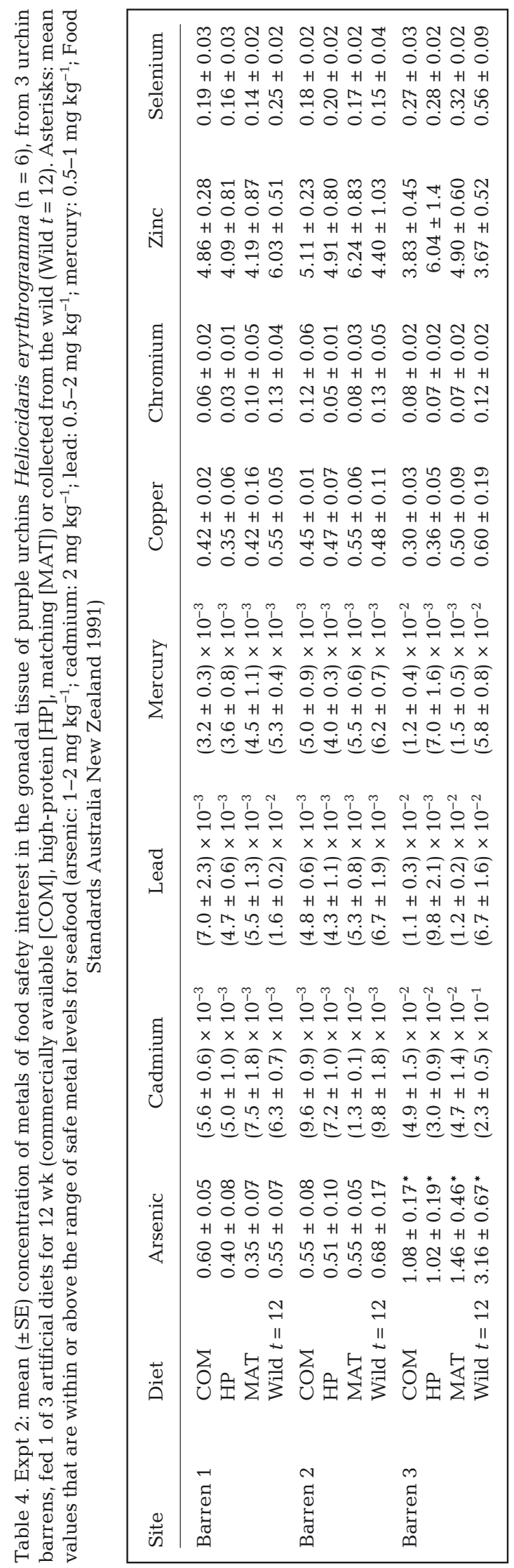

Table 5. Expt 2: 2-way ANOVA for metal concentrations in the gonadal tissue of Heliocidaris erythrogramma $(\mathrm{n}=6)$ from urchin barrens in Port Phillip Bay that were fed manufactured diets or remained in the wild for $12 \mathrm{wk}$. A Bonferroni correction was used to account for multiple tests $(\alpha=$ 0.00625). Cadmium, Selenium, Lead (207): log transformed; Arsenic, Chromium, Mercury (200): 4th-root transformed; ${ }^{*} p<0.05 ;{ }^{* *} p<0.01$

\begin{tabular}{|c|c|c|c|c|}
\hline Heavy metals & Source & $\mathrm{df}$ & MS & $F$ \\
\hline Arsenic & $\begin{array}{c}\text { Site } \\
\text { Diet } \\
\text { Site } \times \text { diet } \\
\text { Residuals }\end{array}$ & $\begin{array}{c}2 \\
3 \\
6 \\
60\end{array}$ & $\begin{array}{l}0.5751 \\
0.0787 \\
0.0401 \\
0.0122\end{array}$ & $\begin{array}{c}47.227^{* *} \\
6.465^{*} \\
3.294\end{array}$ \\
\hline Cadmium & $\begin{array}{c}\text { Site } \\
\text { Diet } \\
\text { Site } \times \text { diet } \\
\text { Residuals }\end{array}$ & $\begin{array}{c}2 \\
3 \\
6 \\
60\end{array}$ & $\begin{array}{r}33.63 \\
2.49 \\
1.66 \\
0.33\end{array}$ & $\begin{array}{c}102.788^{* *} \\
7.623^{*} \\
5.068^{*}\end{array}$ \\
\hline Selenium & $\begin{array}{c}\text { Site } \\
\text { Diet } \\
\text { Site } \times \text { diet } \\
\text { Residuals }\end{array}$ & $\begin{array}{c}2 \\
3 \\
6 \\
60\end{array}$ & $\begin{array}{l}4.089 \\
0.377 \\
0.513 \\
0.184\end{array}$ & $\begin{array}{l}22.263^{* *} \\
2.06 \\
2.795\end{array}$ \\
\hline Lead (207) & $\begin{array}{c}\text { Site } \\
\text { Diet } \\
\text { Site } \times \text { diet } \\
\text { Residuals }\end{array}$ & $\begin{array}{c}2 \\
3 \\
6 \\
60\end{array}$ & $\begin{array}{l}8.965 \\
5.102 \\
0.981 \\
0.333\end{array}$ & $\begin{array}{c}26.951^{* *} \\
15.338^{* *} \\
2.949\end{array}$ \\
\hline Copper & $\begin{array}{c}\text { Site } \\
\text { Diet } \\
\text { Site } \times \text { diet } \\
\text { Residuals }\end{array}$ & $\begin{array}{c}2 \\
3 \\
6 \\
60\end{array}$ & $\begin{array}{l}0.01971 \\
0.07433 \\
0.02811 \\
0.03866\end{array}$ & $\begin{array}{l}0.510 \\
2.520 \\
0.727\end{array}$ \\
\hline Chromium & $\begin{array}{c}\text { Site } \\
\text { Diet } \\
\text { Site } \times \text { diet } \\
\text { Residuals }\end{array}$ & $\begin{array}{c}2 \\
3 \\
6 \\
60\end{array}$ & $\begin{array}{l}0.01835 \\
0.04014 \\
0.00491 \\
0.01433\end{array}$ & $\begin{array}{l}1.280 \\
2.801 \\
0.343\end{array}$ \\
\hline Zinc & $\begin{array}{c}\text { Site } \\
\text { Diet } \\
\text { Site } \times \text { diet } \\
\text { Residuals }\end{array}$ & $\begin{array}{c}2 \\
3 \\
6 \\
60\end{array}$ & $\begin{array}{l}4.205 \\
1.149 \\
6.579 \\
3.513\end{array}$ & $\begin{array}{l}1.197 \\
0.327 \\
1.873\end{array}$ \\
\hline Mercury (200) & $\begin{array}{c}\text { Site } \\
\text { Diet } \\
\text { Site } \times \text { diet } \\
\text { Residuals }\end{array}$ & $\begin{array}{c}2 \\
3 \\
6 \\
60\end{array}$ & $\begin{array}{l}0.08759 \\
0.03040 \\
0.01114 \\
0.00316\end{array}$ & $\begin{array}{c}27.720^{* *} \\
9.621^{* *} \\
3.525^{*}\end{array}$ \\
\hline
\end{tabular}

initial collection $(7.6 \pm 0.3 \%)$ (Fig. 6a). Conversely, COOLING urchins had a mean GI of $8.5 \pm 0.5 \%$, which was an increase of $12.4 \%$ compared to the initial collection (Fig. 6a). There was no significant difference in diameter $\left(F_{1,10}=0.1, \mathrm{p}>0.05\right)$ or wet weight $\left(F_{1,10}=0.1, \mathrm{p}>0.05\right)$ between treatments.

During the experiment, $20 \%$ of WARM and $5 \%$ of COOLING urchins died, which was a significant difference in mortality between treatments (log rank test $=4.9, \mathrm{df}=1, \mathrm{p}<0.05)$. Of the WARM mortalities, onethird had lesions on their test, while no COOLING urchins had visible lesions. Half of all deaths occurred in the last week of the experiment. 
Fig. 6. Expt 3: (a) mean $\pm 95 \%$ confidence interval gonad index (\%) between purple urchins collected from the wild at the start (Wild $t=0$ ) and end of the experiment (Wild $t=10$ ), and urchins fed a pellet diet and held at $22^{\circ} \mathrm{C}$ (Warm) and at gradually declining water temperatures $\left(18-15.5^{\circ} \mathrm{C}\right.$; Cooling). Urchins were collected from Williamstown, Victoria in March $2016(t=0)$ and May $2016(t=$ 10). Mean \pm SE (b) brightness, (c) chroma and (d) hue of urchins conditioned in gradually declining water temperatures $\left(18-15.5^{\circ} \mathrm{C}_{i}\right.$ Cooling), at $22^{\circ} \mathrm{C}$ (Warm) and urchins collected from the wild (Wild $t=10$ )
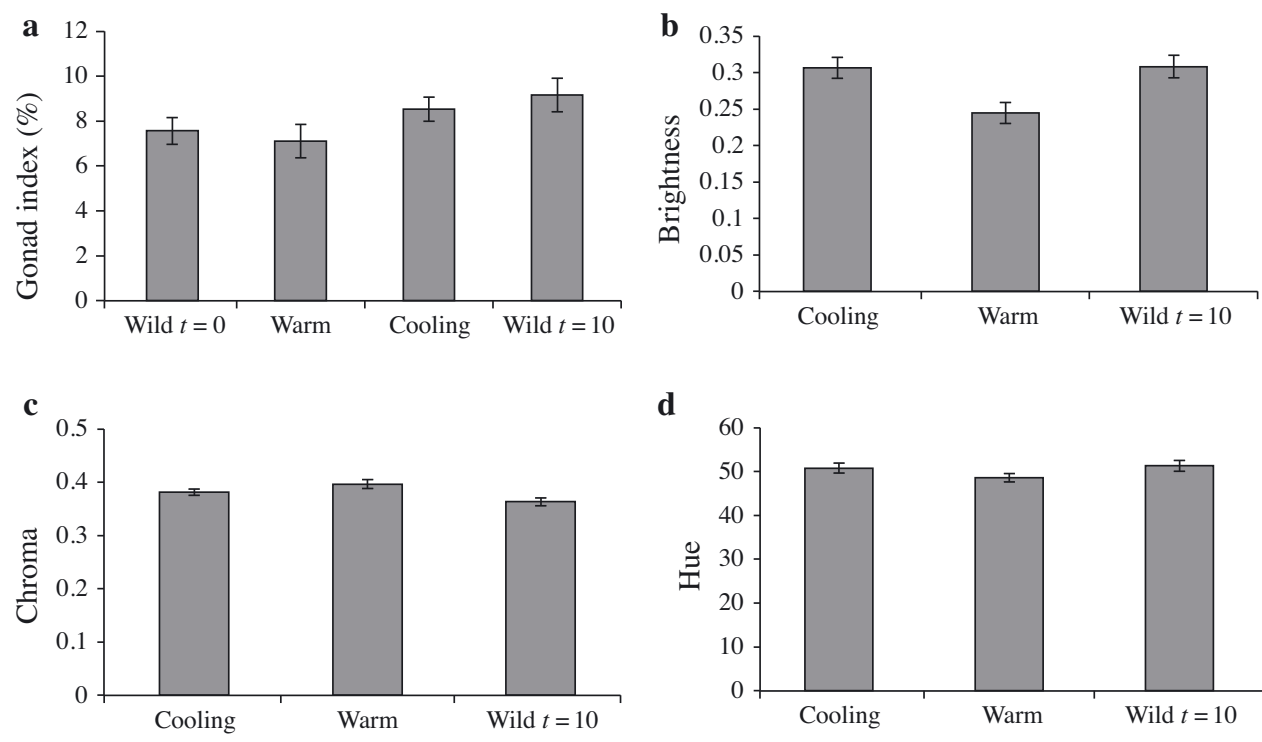

d

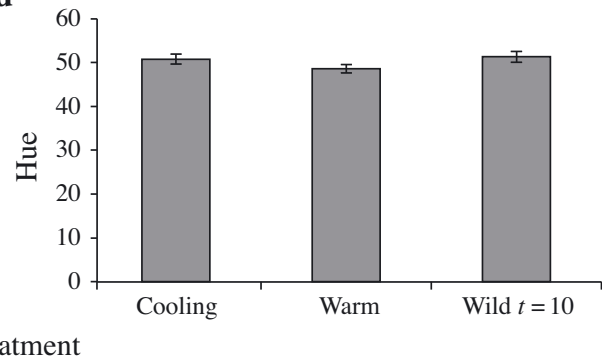

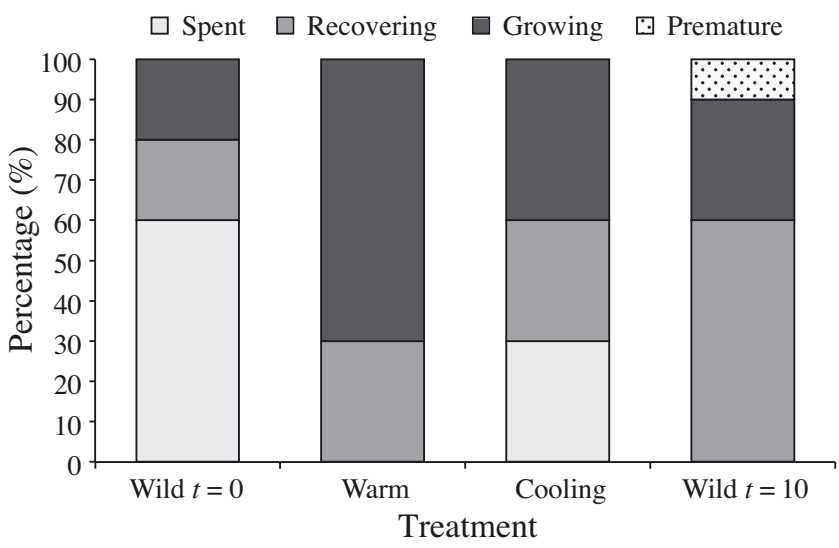

Fig. 7. Expt 3: percentage of purple urchins Heliocidaris erythrogramma at different reproductive stages described by Laegdsgaard et al. (1991): spent, recovering, growing and premature. No sampled urchins were in the mature or partly-spawned reproductive stage. Purple urchins $(\mathrm{n}=10)$ were sampled from Williamstown, Port Phillip Bay at the beginning of the experiment in March 2016 (Wild $t=0$ ), after $12 \mathrm{wk}$ of gonad conditioning at water temperatures mimicking seasonal decline $\left(18-15.5^{\circ} \mathrm{C}\right.$; Cooling), after $12 \mathrm{wk}$ of gonad conditioning at $22^{\circ} \mathrm{C}$ (Warm) and at the end of the experiment from the wild in May 2016 (Wild $t=10$ )

In May, wild urchins had a mean GI of $9.2 \pm 0.02 \%$, which was a $21.2 \%$ increase compared to the wild urchins in March (GI: $7.6 \pm 0.3 \%$; Fig. 6a). GI differed between wild urchins and conditioned urchins $\left(F_{2,127}=\right.$ 8.2, $\mathrm{p}<0.001)$. The mean GI of WARM urchins was $22 \%$ lower than the wild urchins (GI: $9.2 \pm 0.4 \%$; $<$ $0.05)$, while there was no difference in GI between wild and COOLING urchins ( $p>0.05$; Fig. 6a).
Gonad quality and reproductive stages

Gonad conditioning at $22^{\circ} \mathrm{C}$ had a negative effect on gonad brightness $\left(\chi_{2}^{2}=13, \mathrm{p}<0.01\right.$; Fig. $\left.6 \mathrm{~b}\right)$. On average, wild and COOLING urchins were $20 \%$ brighter than WARM urchins ( $p<0.05$ for both comparisons). There was no difference in brightness between wild and COOLING urchins ( $p>0.05)$. Conversely, treatment had no effect on chroma $\left(\chi^{2}{ }_{2}=4\right.$, $\mathrm{p}=0.1$; Fig. $6 \mathrm{c})$ or hue $\left(\chi_{2}^{2}=3, \mathrm{p}=0.3\right.$; Fig. $\left.6 \mathrm{~d}\right)$.

Urchins from the initial wild collection were in the spent, recovering and growing stages. The majority of these urchins were in the recovering stage $(60 \%)$, indicating that they had spawned over summer (Fig. 7). After conditioning, urchins from the COOLING treatment were spread relatively evenly between the spent, recovering and growing stages (Fig. 7), while $70 \%$ of WARM urchins had progressed to the growing stage with one urchin in the premature stage (Fig. 7). Additionally, $60 \%$ of urchins sampled from the wild in May were in the recovering stage with urchins also in the growing and premature stages (Fig. 7).

\section{DISCUSSION}

Developing a sea urchin aquaculture industry as a driver to reduce urchin densities in barrens requires an assessment of urchin gonad variation and the knowledge of whether urchins from barrens can reach commercial quantity and quality through gonad conditioning. Here, we found that in-season gonad con- 
ditioning using artificial diets can increase the GI of urchins from barrens to a commercially viable level, and that site was a more important predictor of purple urchin GI than habitat type.

\section{Spatio-temporal variability in gonad index}

In Expt 1, urchins from kelp beds had higher GI than urchins from barrens within a site. However, urchins from Gellibrand had consistently higher GI values than urchins from Mornington, regardless of whether the urchins came from barren or kelp bed habitats (Fig. 2). In addition, the 2 sites with the highest mean wild GI in Expt 2 were urchin barrens (Barrens 1 and 2; Fig. 3a). These findings are inconsistent with many studies that characterise urchins from barrens as having smaller GI values than urchins from kelp beds (Sanderson et al. 1996, Worthington \& Blount 2003, James et al. 2007, Ling \& Johnson 2009).

The prevalence of drift algae in parts of PPB may explain why urchin roe quantity in certain barrens was higher than expected. Drift algal mats may subsidise the diet of urchins from unproductive habitats despite an absence of attached macroalgae (Chidgey \& Edmunds 1997, Filbee-Dexter \& Scheibling 2014a). A similar phenomenon has been documented off the coast of Nova Scotia, where the diet of urchins from barrens is supplemented by unattached macroalgae from neighbouring kelp beds (Kelly et al. 2012). Heliocidaris erythrogramma is a preferential drift-feeder and is likely to profit from drift algae when it is available (Sanderson et al. 1996, Vanderklift \& Kendrick 2005, Vanderklift \& Wernberg 2008). In addition, drift algae is most prevalent in the northwest of PPB, which may explain why Barrens 1 and 2, in the northwest and west of $\mathrm{PPB}$, respectively, have higher quality urchins than other sites (Chidgey \& Edmunds 1997).

Collection period was also a significant predictor of GI and determined the optimal time for harvest and gonad conditioning. Purple urchins had maximum GI in spring (Fig. 2), a sharp decline in GI during the summer spawning season (Williams \& Anderson 1975, Dix 1977, Laegdsgaard et al. 1991) followed by low GI until autumn-winter (Fig. 2). This is similar to the seasonal GI pattern of $H$. erythrogramma in Tasmania, Australia (Dix 1977, Sanderson et al. 1996). This pattern indicates that gonad conditioning should start in winter and end in spring to obtain the highest amount of roe; conditioning after the summer spawning period is typically difficult as urchins have low GI (Williams \& Anderson 1975, Dix 1977, Laegdsgaard et al. 1991).

\section{In-season gonad conditioning}

Gonad conditioning improved the GI of purple urchins from barrens to a commercial level (i.e. $>10 \%$ GI) during the harvest period (mean GI: 16\%; Fig. 3a). These results are consistent with previous studies on other urchin species around the world, which have shown that manufactured diets are more effective at increasing GI than kelp diets (de JongWestman et al. 1995, Shpigel et al. 2004, Musgrove 2005, James 2006, Woods et al. 2008, Phillips et al. 2010, Cyrus et al. 2013). Artificial diets resulted in mean GI values above $10 \%$, regardless of site, which is better than other attempts at gonad conditioning of H. erythrogramma (Sanderson et al. 1996, Musgrove 2005, Senaratna et al. 2005).

The HP and MAT diets performed better than the COM diet at increasing GI (Fig. 3b). This is likely due to variation in the ingredients of the diets, as opposed to gross variation in nutritional content, as the MAT and COM diets contained similar levels of protein and lipids (Table 1). Further, the HP diet contained more protein than the MAT diet (Table 1) with no significant improvement in GI. This suggests that higher protein content does not necessarily improve GI, and that $335 \mathrm{~g} \mathrm{~kg}^{-1}$ of protein in a diet is sufficient to guarantee good performance. Additional diet development studies should assess if different protein, lipid, carbohydrate or energy levels might further boost GI.

Despite the marked benefit of gonad conditioning on GI, its effect on gonad quality varied primarily due to the site from which the urchins originated. Generally, urchins from Barren 3 benefited more from gonad conditioning than urchins from Barrens 1 and 2. Wild urchins from Barren 3 were of poorer quality than urchins from the other barrens, illustrated by their darker roe (Fig. 4a) containing higher levels of metals (Table 4). After conditioning, the roe of urchins from Barren 3 was lighter (Fig. 4a), more orange in colour (Fig. 4c), had better grade scores (Fig. 5a) and contained lower concentrations of arsenic, cadmium, lead and mercury than wild urchins (Table 4). This is consistent with James et al. (2007), who found that urchins with poor initial gonad quality benefited more from gonad conditioning than urchins with higher initial gonad quality. Improvement in gonad quality from an artificial diet contrasts with numerous studies where algal diets produced roe of better colour than artificial diets (Shpigel et al. 2004, Phillips et al. 2009, 2010, Eddy et al. 2012, Cyrus et al. 2013). However, gonad conditioning did not improve the overall gonad quality of urchins from 
Barren 1 (Fig. 5b) or Barren 2 (Fig. 5c), highlighting the need for further diet development targeted at improving colour, texture and firmness of roe.

As gonad conditioning elicits a varied response in urchins from different sites, harvesters should collect urchins from higher quality barren sites, such as Barren 1 , to ensure a high-quality product after gonad conditioning. In particular, harvesters should avoid collecting from sites known to have high metal concentrations due to the negative relationship between metal concentration and commercial quality of sea urchin roe. Past research has linked high metal concentrations with impairments in gamete quality and embryonic development of sea urchins (Guillou et al. 2000, Au et al. 2001a,b, Soualili et al. 2008) and colour changes in marine invertebrates (Funes et al. 2006, Martínez et al. 2014), which may explain this relationship. Despite this, gonad conditioning reduced the arsenic concentrations of urchins from polluted waters (Table 4), suggesting that gonad conditioning may improve the food safety of wild urchins.

\section{Out-of-season gonad conditioning}

Conditioning purple urchins outside of the $5 \mathrm{mo}$ harvest season to produce high-quality roe would increase production flexibility with possible market advantages. Gonad conditioning at spring-summer temperatures increased the GI of numerous urchin species (Evechinus chloroticus: James \& Heath 2008a, James et al. 2009; Paracentrotus lividus: Spirlet et al. 2000; Strongylocentrotus droebachiensis: Siikavuopio et al. 2006, 2008; S. purpuratus: Azad et al. 2011; Glyptocidaris crenularis: Zhao et al. 2015) but was ineffective for purple urchins (Fig. 6a). Urchins from the WARM treatment did progress faster through the reproductive cycle than COOLING urchins (Fig. 7), however, this did not result in increased GI as predicted (Fig. 6a).

The presence of lesions on WARM urchins indicated that disease might have been responsible for the increased mortality and poorer quality gonads in the $22^{\circ} \mathrm{C}$ treatment. The opportunistic pathogen Vibrio anguillarum is prevalent in PPB and causes lesions and death in $H$. erythrogramma (Sweet et al. 2016). Notably, the disease is influenced by temperature, with an increase in transmission rates and prevalence at higher temperatures (Sweet et al. 2016).

Gonad conditioning was not effective at increasing the GI of COOLING urchins compared to wild urchins (Fig. 6a). This suggests that the COM diet provided no advantage over a wild algal diet for post-spawned urchins despite its efficacy in improving the GI of urchins from barrens during the harvest season (Expt 2). As $60 \%$ of COOLING urchins were in the spent and recovering reproductive stages (Fig. 7), it is not surprising that GI was low (Dix 1977, Laegdsgaard et al. 1991). It is possible that urchins in the recovering stage may be unable to reach commercial gonad quantity. Thus, more research is needed to create a diet specific to gonad conditioning of post-spawned urchins and to explore what reproductive stages are most receptive to gonad conditioning. Future research should also explore the effect of photoperiod on increasing the GI of post-spawned purple urchins. Photoperiod has been used effectively to control the reproductive cycle of $S$. droebachiensis (Walker \& Lesser 1998, Böttger et al. 2006, Kirchhoff et al. 2010). However, the effect of photoperiod on $H$. erythrogramma has not been well explored.

\section{Commercial and environmental implications}

The effectiveness of gonad conditioning on purple urchins from barrens provides a unique opportunity for a sea urchin aquaculture industry to establish and access the 4300 tons of purple urchins in barrens in PPB (Worthington \& Blount 2003). In addition, urchins from some barren sites are of commercial quantity and quality without gonad conditioning. These unexpected results further incentivise harvest from barrens, especially for the existing fishery, which does not currently harvest from these areas.

As there is variation in gonad quality between sites, an industry should have a flexible production strategy. Due to the cost of gonad conditioning, we recommend sampling urchins before deciding whether gonad conditioning is required. If urchins from barrens are of commercial quality, perhaps due to increased drift availability, the fishery and aquaculture industry can harvest these urchins and sell them immediately. However, as gonad conditioning can result in an increase in GI of 33 to $196 \%$, depending on the site, gonad conditioning will likely result in greater profits than the sale of wild urchins.

Harvesting urchins from barrens could create commercial and ecological benefits on a local and global scale. From an environmental perspective, the greatest benefit of commercial harvest from urchin barrens is its ability to aid in kelp forest restoration. However, urchin densities must be reduced to a level considerably lower than the initial density that caused the original phase shift for kelp beds to reestablish (Ling et al. 2009, 2015, Filbee-Dexter \& 
Scheibling 2014b, Kriegisch et al. 2016). Purple urchin densities in barrens must be lower than 4 urchins $\mathrm{m}^{-2}$ to allow kelp recovery (Johnson et al. 2015, Kriegisch et al. 2016). As a result, approximately $70 \%$ of urchins must be removed from most barrens in PPB to return to a kelp-dominated state.

However, $H$. erythrogramma have a relatively short larval stage and limited dispersal capacity, which makes them vulnerable to overfishing (Worthington \& Blount 2003). Therefore, sustainable harvest levels for an aquaculture industry will need to be assessed in conjunction with a site-specific assessment of urchin densities required for kelp recovery. To create a sustainable industry that also depletes urchin numbers in barrens, we recommend a modest overall harvest rate (e.g. $5 \%$ of total urchin biomass) that includes intense harvesting ( $>70 \%$ of urchins) from barrens on reefs with the greatest need for kelp restoration.

The creation of a sea urchin aquaculture industry will also have significant economic benefits. To illustrate the potential profits of an industry, an overall harvest rate of $5 \% \mathrm{yr}^{-1}$ of total urchin biomass from barrens (215 tons) would produce over A $\$ 5.375$ million in urchin roe for an industry, based on a harvest GI of $10 \%$ and $A \$ 250 \mathrm{~kg}^{-1}$ price for roe (Sanderson et al. 1996, Worthington \& Blount 2003).

As urchin barrens are widespread, gonad conditioning of urchins from barrens is a global opportunity. Commercially valuable urchin species are overabundant in New Zealand, Canada, Italy, Japan, the USA and other areas of Australia (Andrew et al. 2002, Ling et al. 2015). Conditioned urchins from barrens could, therefore, supplement the urchin fisheries in these nations, some of which are struggling with low production numbers due to overfishing in kelp bed areas (Andrew et al. 2002). Commercial urchin harvest from barrens would decrease urchin numbers in barrens, which may promote the re-establishment of macroalgae and a shift back to kelp-dominated rocky reefs on a global scale.

Acknowledgements. This study was partially funded by the Rural Industries Research and Development Corporation (PRJ-010410). Support for the urchin GI surveys was provided by the Victorian Government's Seagrass and Reefs program (to S.E.S.), a Holsworth Wildlife Research Endowment-Equity Trustees Charitable Foundation grant (to N.K.), the University of Tasmania and the Victorian Department of Environment, Land, Water and Planning. We thank Dean Chamberlain, Luke Barrett, Dr. Valeriya Komyakova, Dr. Simon Reeves and Dr. Scott Ling for urchin collection; Rod Watson and John Ahern for experimental assistance; Dr. Devi Stuart-Fox and Katrina Rankin for help with colour analysis; Irene Volitakis for performing metal analysis; and Aquafeeds Australia for providing the commercial diet.

\section{LITERATURE CITED}

Andrew NL, Underwood AJ (1993) Density-dependent foraging in the sea urchin Centrostephanus rodgersii on shallow subtidal reefs in New South Wales, Australia. Mar Ecol Prog Ser 99:89-98

Andrew NL, Agatsuma Y, Ballesteros E, Bazhin AG and others (2002) Status and management of world sea urchin fisheries. Oceanogr Mar Biol Annu Rev 40:343-425

Au DWT, Lee CY, Chan KL, Wu RSS (2001a) Reproductive impairment of sea urchins upon chronic exposure to cadmium. Part I: Effects on gamete quality. Environ Pollut 111:1-9

Au DWT, Reunov AA, Wu RSS (2001b) Reproductive impairment of sea urchin upon chronic exposure to cadmium. Part II: Effects on sperm development. Environ Pollut 111:11-20

Azad AK, Pearce CM, McKinley RS (2011) Effects of diet and temperature on ingestion, absorption, assimilation, gonad yield, and gonad quality of the purple sea urchin (Strongylocentrotus purpuratus). Aquaculture 317:187-196

* Blount C, Worthington D (2002) Identifying individuals of the sea urchin Centrostephanus rodgersii with highquality roe in New South Wales, Australia. Fish Res 58: 341-348

*Böttger SA, Devin MG, Walker CW (2006) Suspension of annual gametogenesis in North American green sea urchins (Strongylocentrotus droebachiensis) experiencing invariant photoperiod-applications for land-based aquaculture. Aquaculture 261:1422-1431

Chapman ARO (1981) Stability of sea urchin dominated barren grounds following destructive grazing of kelp in St. Margaret's Bay, eastern Canada. Mar Biol 62:307-311

Chidgey SS, Edmunds M (1997) Standing crop and nutrient content of macrophytes in Port Phillip Bay. Port Phillip Bay Environmental Study. CSIRO Environmental Projects Office, Canberra

Cho CY, Slinger SJ (1979) Apparent digestibility measurements in feedstuffs for rainbow trout. In: Halver J, Tiews $\mathrm{K}$ (eds) Finfish nutrition and fish feed technology, Vol 2. Heeneman, Berlin, p 239-247

Constable A (1989) An investigation of resource allocation in the sea urchin Heliocidaris erythrogramma (Valenciennes). PhD thesis, The University of Melbourne

* Cyrus MD, Bolton JJ, de Wet L, Macey BM (2013) The development of a formulated feed containing Ulva (Chlorophyta) to promote rapid growth and enhanced production of high quality roe in the sea urchin Tripneustes gratilla (Linnaeus). Aquacult Res 45:159-176

* de Jong-Westman M, March BE, Carefoot TH (1995) The effect of different nutrient formulations in artificial diets on gonad growth in the sea urchin Strongylocentrotus droebachiensis. Can J Zool 73:1495-1502

* Dix TG (1977) Reproduction in Tasmanian populations of Heliocidaris erythrogramma (Echinodermata: Echinometridae). Mar Freshw Res 28:509-520

Eddy SD, Brown NP, Kling AL, Watts SA, Lawrence A (2012) Growth of juvenile green sea urchins, Strongylocentrotus droebachiensis, fed formulated feeds with varying protein levels compared with a macroalgal diet and a commercial abalone feed. J World Aquacult Soc 43: 159-173

Endler JA (1990) On the measurement and classification of colour in studies of animal colour patterns. Biol J Linn Soc 41:315-352 
Filbee-Dexter K, Scheibling RE (2014a) Detrital kelp subsidy supports high reproductive condition of deep-living sea urchins in a sedimentary basin. Aquat Biol 23:71-86

Filbee-Dexter K, Scheibling RE (2014b) Sea urchin barrens as alternative stable states of collapsed kelp ecosystems. Mar Ecol Prog Ser 495:1-25

Food Standards Australia New Zealand (1991) Australia New Zealand Food Standards Code. Standard 1.4.1: contaminants and natural toxicants. www.legislation.gov.au/ Details/F2016C00167 (accessed 23 May 2017)

Funes V, Alhama J, Navas JI, López-Barea J, Peinado J (2006) Ecotoxicological effects of metal pollution in two mollusc species from the Spanish South Atlantic littoral. Environ Pollut 139:214-223

Garcia JE, Dyer AG, Greentree AD, Spring G, Wilksch PA (2013) Linearisation of RGB camera responses for quantitative image analysis of visible and UV photography: a comparison of two techniques. PLOS ONE 8:e79534

Guillou M, Quiniou F, Huart B, Pagano G (2000) Comparison of embryonic development and metal contamination in several populations of the sea urchin Sphaerechinus granularis (Lamarck) exposed to anthropogenic pollution. Arch Environ Contam Toxicol 39:337-344

*Huguet CT, Norambuena F, Emery JA, Hermon K, Turchini GM (2015) Dietary n-6/n-3 LC-PUFA ratio, temperature and time interactions on nutrients and fatty acids digestibility in Atlantic salmon. Aquaculture 436:160-166

James PJ (2006) The effects of wave and feeding disturbance on roe enhancement of the sea urchin Evechinus chloroticus held in sea-cages. Aquaculture 252:361-371

James PJ, Heath PL (2008a) The effects of season, temperature and photoperiod on the gonad development of Evechinus chloroticus. Aquaculture 285:67-77

James PJ, Heath PL (2008b) Long term roe enhancement of Evechinus chloroticus. Aquaculture 278:89-96

James PJ, Heath P, Unwin MJ (2007) The effects of season, temperature and initial gonad condition on roe enhancement of the sea urchin Evechinus chloroticus. Aquaculture 270:115-131

James P, Heath P, Green K, Wright J (2009) The effect of elevated temperature on roe enhancement of Evechinus chloroticus collected from two latitudes. Aquaculture 288:273-279

Johnson C, Swearer S, Ling S, Reeves S and others (2015) The reef ecosystem evaluation framework: managing for resilience in temperate environments. Department of Environment, Land, Water and Planning, Melbourne

Kelly JR, Krumhansl KA, Scheibling RE (2012) Drift algal subsidies to sea urchins in low-productivity habitats. Mar Ecol Prog Ser 452:145-157

* Kirchhoff NT, Eddy S, Brown NP (2010) Out-of-season gamete production in Strongylocentrotus droebachiensis: photoperiod and temperature manipulation. Aquaculture 303:77-85

Kriegisch N, Reeves S, Johnson CR, Ling SD (2016) Phaseshift dynamics of sea urchin overgrazing on nutrified reefs. PLOS ONE 11:e0168333

Laegdsgaard P, Byrne M, Anderson D (1991) Reproduction of sympatric populations of Heliocidaris erythrogramma and $H$. tuberculata (Echinoidea) in New South Wales. Mar Biol 110:359-374

Ling SD (2008) Range expansion of a habitat-modifying species leads to loss of taxonomic diversity: a new and impoverished reef state. Oecologia 156:883-894

Ling SD, Johnson CR (2009) Population dynamics of an eco- logically important range-extender: kelp beds versus sea urchin barrens. Mar Ecol Prog Ser 374:113-125

* Ling SD, Johnson CR, Frusher SD, Ridgway KR (2009) Overfishing reduces resilience of kelp beds to climate-driven catastrophic phase shift. Proc Natl Acad Sci USA 106: 22341-22345

KLing SD, Scheibling RE, Rassweiler A, Johnson CR and others (2015) Global regime shift dynamics of catastrophic sea urchin overgrazing. Philos Trans R Soc B 370:20130269

* Martínez A, Romero Y, Castillo T, Mascaró M and others (2014) The effect of copper on the color of shrimps: redder is not always healthier. PLOS ONE 9:e107673

Musgrove RJ (2005) Aquaculture and diet development subprogram: post harvest enhancement of sea urchin roe for the Japanese market. SARDI Aquatic Sciences, Adelaide

* Myers WD, Ludden PA, Nayigihugu V, Hess BW (2004) Technical note: a procedure for the preparation and quantitative analysis of samples for titanium dioxide. J Anim Sci 82:179-183

* Phillips K, Bremer P, Silcock P, Hamid N, Delahunty C, Barker M, Kissick J (2009) Effect of gender, diet and storage time on the physical properties and sensory quality of sea urchin (Evechinus chloroticus) gonads. Aquaculture 288:205-215

* Phillips K, Hamid N, Silcock P, Sewell MA and others (2010) Effect of manufactured diets on the yield, biochemical composition and sensory quality of Evechinus chloroticus sea urchin gonads. Aquaculture 308:49-59

Quinn GP, Keough MJ (2002) Experimental design and data analysis for biologists. Cambridge University Press, Cambridge

R Development Core Team (2015) R: a language and environment for statistical computing. R Foundation for Statistical Computing, Vienna. www.r-project.org

Reynolds A, Newman C (2015) Palos Verdes kelp forest restoration project: 2015 annual report. The Bay Foundation, Los Angeles, CA. www.santamonicabay.org/ wp-content/uploads/2014/04/Kelp-Restoration-AnnualReport-October-2015-Final.pdf (accessed 15 May 2017)

Russell MP (1998) Resource allocation plasticity in sea urchins: rapid, diet induced, phenotypic changes in the green sea urchin, Strongylocentrotus droebachiensis (Müller). J Exp Mar Biol Ecol 220:1-14

Sanderson JC, Le Rossignol M, James W (1996) A pilot program to maximise Tasmania's sea urchin (Heliocidaris erythrogramma) resource. Fisheries Research \& Development Corporation, Canberra. https://eprints.utas.edu.au/11926/ 1/JCSUrchFRDCChpt0_1_2_3.pdf (accessed 16 May 2017)

Sanderson JC, Ling SD, Dominguez JG, Johnson CR (2016) Limited effectiveness of divers to mitigate 'barrens' formation by culling sea urchins while fishing for abalone. Mar Freshw Res 67:84-95

* Senaratna M, Evans LH, Southam L, Tsvetnenko E (2005) Effect of different feed formulations on feed efficiency, gonad yield and gonad quality in the purple sea urchin Heliocidaris erythrogramma. Aquacult Nutr 11:199-207

* Shears NT, Babcock RC (2002) Marine reserves demonstrate top-down control of community structure on temperate reefs. Oecologia 132:131-142

* Shpigel M, McBride SC, Marciano S, Lupatsch I (2004) The effect of photoperiod and temperature on the reproduction of European sea urchin Paracentrotus lividus. Aquaculture 232:343-355

* Siikavuopio SI, Christiansen JS, Dale T (2006) Effects of temperature and season on gonad growth and feed 
intake in the green sea urchin (Strongylocentrotus droebachiensis). Aquaculture 255:389-394

Siikavuopio SI, Mortensen A, Christiansen JS (2008) Effects of body weight and temperature on feed intake, gonad growth and oxygen consumption in green sea urchin, Strongylocentrotus droebachiensis. Aquaculture 281: 77-82

Smith KR, Cadena V, Endler JA, Kearney MR, Porter WP, Stuart-Fox D (2016) Color change for thermoregulation versus camouflage in free-ranging lizards. Am Nat 188: 668-678

Sonu SC (1995) The Japanese sea urchin market. NOAA Technical Memo NMFS-SWR-030. US Department of Commerce, Washington, DC

Soualili D, Dubois P, Gosselin P, Pernet P, Guillou M (2008) Assessment of seawater pollution by heavy metals in the neighbourhood of Algiers: use of the sea urchin, Paracentrotus lividus, as a bioindicator. ICES J Mar Sci 65:132-139

Spirlet C, Grosjean P, Jangoux M (2000) Optimization of gonad growth by manipulation of temperature and photoperiod in cultivated sea urchins, Paracentrotus lividus (Lamarck) (Echinodermata). Aquaculture 185:85-99

Steneck RS, Graham MH, Bourque BJ, Corbett D, Erlandson JM, Estes JA, Tegner MJ (2002) Kelp forest ecosystems: biodiversity, stability, resilience and future. Environ Conserv 29:436-459

Stevens M, Párraga CA, Cuthill IC, Partridge JC, Troscianko TS (2007) Using digital photography to study animal coloration. Biol J Linn Soc 90:211-237

Sweet M, Bulling M, Williamson JE (2016) New disease outbreak affects two dominant sea urchin species associated with Australian temperate reefs. Mar Ecol Prog Ser 551: 171-183

Tracey S, Mundy C, Baulch T, Marzloff M, Hartmann K, Ling S, Tisdell J (2014) Trial of an industry implemented, spatially discrete eradication/control program for Centrostephanus rodgersii in Tasmania. Fisheries Research and Development Corporation, Canberra. www.imas. utas.edu.au/_data/assets/pdf_file/0008/743093/trial-of-

Editorial responsibility: Philippe Archambault,

Rimouski, Québec, Canada an-industry-implemented.pdf (accessed 16 May 2017)

* Tracey SR, Baulch T, Hartmann K, Ling SD, Lucieer V, Marzloff MP, Mundy C (2015) Systematic culling controls a climate driven, habitat modifying invader. Biol Invasions $17: 1885-1896$

V Vadas R, Beal B, Dowling T, Fegley J (2000) Experimental field tests of natural algal diets on gonad index and quality in the green sea urchin, Strongylocentrotus droebachiensis: a case for rapid summer production in postspawned animals. Aquaculture 182:115-135

Vanderklift MA, Kendrick GA (2005) Contrasting influence of sea urchins on attached and drift macroalgae. Mar Ecol Prog Ser 299:101-110

*Vanderklift MA, Wernberg T (2008) Detached kelps from distant sources are a food subsidy for sea urchins. Oecologia 157:327-335

*Walker CW, Lesser MP (1998) Manipulation of food and photoperiod promotes out-of-season gametogenesis in the green sea urchin, Strongylocentrotus droebachiensis: implications for aquaculture. Mar Biol 132:663-676

*Williams DHC, Anderson DT (1975) The reproductive system, embryonic development, larval development and metamorphosis of the sea urchin Heliocidaris erythrogramma (Val.) (Echinoidea: Echinometridae). Aust J Zool 23:371-403

Woods CMC, James PJ, Moss GA, Wright J, Siikavuopio S (2008) A comparison of the effect of urchin size and diet on gonad yield and quality in the sea urchin Evechinus chloroticus Valenciennes. Aquacult Int 16:49-68

Worthington D, Blount C (2003) Research to develop and manage the sea urchin fisheries of NSW and eastern Victoria. Fisheries Research and Development Corporation, Cronulla. https://www.dpi.nsw.gov.au/_data/assets/pdf file/0008/545642/FFRS-56_Worthington-and-Blount-2003. pdf (accessed 16 May 2017)

Zhao C, Tian X, Sun P, Hu L, Feng W, Chang Y (2015) Longterm effects of temperature on gonad production, colour and flavour of the sea urchin Glyptocidaris crenularis. J Mar Biol Assoc UK 95:139-143

Submitted: September 6, 2017; Accepted: May 24, 2018 Proofs received from author(s): July 21, 2018 